\title{
O MÉTODO MATERIALISTA E DIALÉTICO DE MARX E ENGELS1
}

\section{EL MÉTODO MATERIALISTA Y DIALÉCTICO DE MARX Y ENGELS}

\section{THE MATERIALIST AND DIALECTICAL METHOD OF MARX AND ENGELS}

\author{
DOI: http://dx.doi.org/10.9771/gmed.v12i3.42063
}

Claus Germer²

\begin{abstract}
Resumo: O objeto do presente artigo é o método da economia política, não em sua particularidade, mas em sua inserção no método de pesquisa geral, baseado no materialismo filosófico e na dialética. Ao contrário da habitual referência ao método 'de Marx', neste artigo se faz referência ao método 'de Marx e Engels'. O método 'de Marx' é objeto de polêmica antiga. A omissão das obras filosóficas e metodológicas de Engels pode ser considerada uma das causas das incompreensões sobre o método. Uma discussão sobre o método de Marx e Engels deveria incluir os autores mais destacados no debate. Porém, isto requer, em primeiro lugar, inteirar-se das obras dos próprios autores do tema. Por esta razão o objetivo do presente artigo é contribuir para a identificação daquilo que, com base nos escritos de ambos os autores, se possa concluir que constitua o seu método.
\end{abstract}

Palavras-chave: método da economia política; método de Marx e Engels; economia política e método materialista e dialético; economia política e materialismo histórico; Engels e o método materialista dialético.

Resumen: El tema de este artículo es el método de la economía política, pero no en su particularidad, sino en su inserción en el método de investigación general, basado en el materialismo filosófico y la dialéctica. Contrariamente a la referencia habitual al método 'de Marx', este artículo se refiere al método 'de Marx y Engels'. El método de Marx es objeto de una controversia duradera. La omisión de las obras filosóficas y metodológicas de Engels puede considerarse una de las causas de los malentendidos sobre el método. Una discusión sobre el método de Marx y Engels debería incluir a los autores más prominentes en el debate. Sin embargo, esto requiere, en primer lugar, conocer las obras de los propios autores. Por esta razón, el objetivo de este artículo es contribuir a la identificación de lo que, sobre la base de los escritos de ambos autores, se puede concluir que constituya su método.

Palabras clave: método de la economía política; método de Marx y Engels; economía política y método materialista y dialéctico; economía política y materialismo histórico; Engels y el método materialista dialéctico.

Abstract: The subject of this article is the method of political economy, but not on its particularity, but on its insertion in the general research method, based on philosophical materialism and dialectics. Contrary to the usual reference to 'Marx's' method, this article refers to 'Marx's and Engels" method. Marx's method is the subject of long lasting controversy. The omission of Engels' philosophical and methodological works can be considered one of the causes of the misunderstandings about the method. A discussion of Marx and Engels' method should include the most prominent authors in the debate. However, this requires, first of all, to know the works of the authors themselves. For this reason, the aim of this article is to contribute to the identification of what, based on the writings of both authors, can be concluded to constitute their method.

Keywords: method of political economy; 'Marx's and Engels" method; political economy and the materialist and dialectical method;; political economy and historical materialism; Engels and the dialectical materialist method.

\section{Introdução}

O método de Marx é objeto de polêmica já antiga mas inconclusiva. Ao pesquisador marxista da economia este debate deveria interessar de modo decisivo, mas não é o que transparece quando se constata a escassez de artigos de economistas marxistas dedicados ao tema. O paradoxo explica-se porque, como se 
argumentará, geralmente não utilizam ou estudam o método geral, mas satisfazem-se apenas com um ramo dele derivado, que é a teoria e o método do materialismo histórico.

Ao contrário da habitual referência ao método 'de Marx', neste artigo se faz referência ao método de 'Marx e Engels', pois ambos o elaboraram conjuntamente - embora a primazia, reconhecida pelo próprio Engels (ENGELS, s/d, b, p. 193), caiba a Marx - e em nada divergiram, no essencial, como se procurará indicar. Sendo assim, quando críticos de elementos do método apontam as suas críticas, talvez taticamente, para Engels - como é o caso de Lukács, como se indicará -, intimidados talvez pela estatura de Marx, atingem também, intencionalmente ou não, o próprio Marx. A omissão das obras filosóficas e metodológicas de Engels pode ser considerada uma das causas das incompreensões sobre o método 'de Marx'.

Uma discussão sobre o método de Marx e Engels deveria incluir as opiniões dos autores marxistas - e mesmo não-marxistas - que mais se destacaram neste debate. No entanto, as obras destes autores expressam as suas próprias interpretações sobre o tema, não o método do próprio Marx, que, aliás, se considera não ter sido adequadamente explicitado por ele, que é um dos motivos da polêmica. Assim, o estudioso interessado em ingressar no debate deve inicialmente, estudar diretamente os escritos de Marx e Engels sobre o tema, a fim de formar a sua própria opinião. Assim, o objetivo do presente artigo é contribuir para a identificação daquilo que, com base nos escritos de ambos os autores, se possa concluir que constitua o seu método.

O método de Marx e Engels permanece como uma espécie de enigma a ser decifrado, uma vez que se alega que não produziram um tratado, ou pelo menos um texto mais detalhado, expondo-o. Lênin, por exemplo, afirmou que, embora Marx não tenha nos deixado um texto sobre a lógica, deixou-nos a lógica de $O$ capital. O aforismo de Lênin tem um fundo de verdade, mas, a melhor exame, Marx e Engels deixaram diversos escritos - além de inúmeras indicações esparsas - referentes especificamente ao método, que contêm, embora de modo sintético, os elementos essenciais do método utilizado em $O$ capital, que é o objeto do presente artigo.

O aforismo de Lenin, citado acima, parece sugerir que, uma vez que Marx não deixou um tratado sobre o método, este, para tornar-se conhecido, teria que ser meticulosamente extraído d'O capital'3. Neste artigo procura-se, em sentido contrário, fundamentar a hipótese de que os principais elementos do método de Marx e Engels foram, em parte, elaborados por eles mesmos, como indicado adiante, e em parte encontrados já elaborados, no essencial, em autores que os influenciaram decisivamente, como são os casos, principalmente, de Hegel e Feuerbach, em relação à dialética e ao materialismo filosófico, respectivamente (ENGELS, s/d, b).

Este artigo focaliza o método de Marx e Engels, e pretende sugerir um esboço do conjunto da matriz teórica e metodológica, que a crítica da economia política de Marx - referência central do marxismo - pressupõe e na qual se insere e se apóia. Deve-se observar que a análise contida em O capital não se limita, teorica e metodologicamente, ao modo de produção capitalista, mas pressupõe e insere-se em uma matriz filosófica, teórica e metodológica que compreende os pilares da explicação da evolução da natureza e da sociedade e, consequentemente, dos modos de produção e da sua sucessão histórica, e constitui a estrutura 
conceitual necessária para dar suporte à descoberta e explicação das leis que presidem o movimento do capital. Isto significa que $O$ capital não teria o formato e o conteúdo que tem sem esta matriz, e que, portanto, os elementos desta, contidos em $O$ capital, podem e devem ser apontados, com base nos escritos metodológicos de Marx e Engels disponíveis.

Os elementos da matriz citada são consistentes com os fundamentos do materialismo filosófico e da dialética materialista, e com os aspectos fundamentais do processo histórico, graças aos quais a sua visão penetrou profundamente nos mecanismos internos do desenvolvimento da sociedade, e mantém-se como a mais rigorosa matriz conceitual para a análise científica da mesma. Constitui, por esta razão, o enquadramento conceitual necessário de $\mathrm{O}$ capital.

Duas distinções significativas serão feitas neste artigo. Em primeiro lugar, propõe-se uma distinção, de extraordinária importância prática para a pesquisa marxista, entre o método de elaboração da teoria e o método de aplicação da teoria à pesquisa da realidade que a mesma representa, que serão denominados, respectivamente, método teórico e método aplicado. Em segundo lugar, o método de estudo da realidade social pode, e deve, ser dividido em níveis analiticamente significativos dispostos em escala hierárquica descendente a partir do método geral, cada um subordinado ao anterior. No topo situa-se o método geral do materialismo dialético, e na base de um dos seus ramos, o materialismo histórico, encontrase o chamado método da economia política, representado pelo $O$ capital.

Uma observação final: a contribuição à exposição do método de Marx e Engels, contida neste artigo, expressa o ponto de vista do pesquisador, especificamente da área de economia. A incursão no campo filosófico, sem possuir formação específica, é, no entanto, necessária ao entendimento do conjunto do método, e é simétrica à incursão do filósofo no campo da pesquisa prática. Ambos confrontam-se na interseção das duas especialidades.

O presente texto possui um caráter necessariamente esquemático, que se deve à intenção de fornecer, aos pesquisadores que se iniciam no marxismo, e reavivar no próprio autor, uma visão de conjunto, como primeira aproximação ao método de Marx e Engels, tal como foi concebido por eles mesmos.

\subsection{O método da economia política}

Quando se fala em método, no marxismo, entende-se mais comumente o método da economia política, certamente porque a obra máxima de Marx, O capital, focaliza a base econômica da sociedade atual, e talvez porque o principal escrito de Marx especificamente sobre o método foi intitulado Método da economia política ${ }^{4}$. No entanto, o método da economia política é um método de pesquisa e estudo apenas de uma esfera particular - a base econômica - dos modos de produção, em especial do capitalismo, uma vez que, em sentido estrito, a economia política surgiu e desenvolveu-se como a teoria econômica do capitalismo. Por outro lado, o modo de produção e a base econômica são temas de apenas uma das grandes subdivisões do método, o materialismo histórico, sendo os outros a dialética da Natureza ${ }^{5}$ e a filosofia, isto é, as concepções materialistas e dialéticas da natureza e do pensamento, respectivamente. O método da economia política não é, portanto, o método de pesquisa da realidade em geral, o qual engloba não uma ou outra esfera 
particular da realidade, mas focaliza esta no maior nível de generalidade ou de abstração, sob o conceito de matéria. No entanto, qualquer método aplicado a qualquer esfera particular deve ter como fundamento os princípios gerais da concepção da matéria. Segue-se disto que se deve entender o método, no marxismo, como o método de pesquisa da realidade em geral, do qual o método de qualquer esfera particular, como o da economia política, é entendido como apenas uma particularização.

\section{O método em geral e seus elementos fundamentais}

\subsection{O que é método}

No sentido geral, do senso comum, o método é o modo de ordenamento de uma atividade com o fim de atingir um objetivo determinado. No sentido específico de meio de geração de conhecimento, isto é, como instrumento de pesquisa, o método é o procedimento necessário para que o ser humano possa reproduzir, no pensamento, o objeto ou fenômeno estudado, ou seja, explicá-lo o mais fielmente possível, no e através do pensamento. O procedimento referido consiste no conjunto de leis do método ou leis do pensamento. O objeto ou fenômeno, tal como reproduzido no pensamento, é uma categoria do pensamento - um conceito ou uma teoria (Marx, 1902-03).

Como o conhecimento, segundo o materialismo, decorre da atividade prática 6 (GERMER, 2003), e sendo a pesquisa científica motivada pelo objetivo consciente de gerar novos conhecimentos sobre um objeto ou fenômeno determinado, segue-se que a pesquisa é essencialmente uma atividade prática, no sentido de Marx, mas uma atividade prática organizada metodicamente. Inicialmente o conhecimento emergiu espontaneamente com base em uma dupla prática, dando origem, por um lado, ao conhecimento da natureza, como resultado da prática produtiva, e, por outro lado, ao conhecimento da sociedade, como resultado da prática social ou das relações em sociedade. Como todo conhecimento é uma reprodução da realidade pelo pensamento, e como o próprio método é uma forma de conhecimento, segue-se que também o método deve ser entendido como uma reprodução da realidade, que, neste caso, consiste no modo pelo qual o cérebro, através do pensamento, reproduz, ou reflete, as leis da realidade como leis do pensamento, como se verá (ENGELS, 1961, p. 227-8) ${ }^{7}$

\subsection{O método da abstração8}

Os conceitos de abstração e do seu produto, o abstrato, são importantíssimos na teoria de Marx e Engels, e no presente artigo eles comparecem inúmeras vezes. Marx atribui à abstração a condição de indispensável método da economia política. Nos seus - e de Engels - primeiros escritos, da década de 1840, e em textos posteriores, ambos dedicam-se repetidas vezes a aprofundar o sentido da abstração e a utilizála na análise dos temas que abordam9. É indispensável, portanto, que os estudiosos marxistas conheçam com profundidade este método e suas implicações, o que evitaria muitas falsas polêmicas, devidas à confusão entre as figuras do pensamento - os abstratos ${ }^{10}$ - e as correspondentes figuras da realidade objetiva, que 
não coincidem. O mesmo vale para o conceito do concreto, o oposto do abstrato, ao qual se chega por intermédio da concreção, oposto da abstração (LANGE, p. 98-112).

A abstração é o método de elaboração de conceitos, desenvolvido espontaneamente ao longo de milênios, antes de ser reconhecido e formalizado pelo ser humano (ver NF 37 e 38). Cada abstrato ou conceito representa não um objeto individual, mas um conjunto de objetos ou fenômenos, e resulta da exclusão mental das características acessórias e na retenção das características distintivas, comuns a todos, que constituem a sua essência. Assim, o abstrato não existe empiricamente como tal, o que existe é o conjunto de objetos dotados da mesma essência, como, por exemplo, a 'fruta', em oposição à laranja, à manga, etc.

A abstração é utilizada por Marx em dois sentidos. Por um lado, como o processo sistemático e originalmente espontâneo de formação de conceitos pelo ser humano (ENGELS und MARX, 1973, p. 5963). Neste sentido, praticamente todos os substantivos são abstrações, isto é, conceitos que expressam as essências dos diferentes conjuntos de objetos ou fenômenos ${ }^{11}$. Este entendimento de Marx está presente na sua exposição da diferença entre os conceitos idealista e materialista de abstração, seu processo e implicações. Marx utiliza como exemplos os conceitos de fruta (Ibidem, p. 60) - já exemplificado por HEGEL (1979, \ 13) -, que pertence ao âmbito da natureza, e de trabalho, pertencente ao âmbito da sociedade ${ }^{12}$, e Engels o de matéria, do âmbito da filosofia ${ }^{13}$, cada um dos quais designa uma coleção de objetos materiais, cada uma com uma essência comum. Teoricamente, portanto, a abstração $\left(A_{b}\right)$ é o método através do qual o ser humano apropria-se da realidade objetiva à sua volta - o concreto real $\left(C_{r}\right)$-, a partir das impressões captadas pelos sentidos - que constituem o concreto sensorial $\left(C_{s}\right)$-, com base na atividade prática e por intermédio da elaboração social de abstrações, inicialmente espontânea, em um caminho que vai do concreto real ao abstrato $\left(C_{r} A_{b}\right)$ (ibidem).

O segundo sentido é como ferramenta intelectual formal das ciências sociais para as operações de análise teórica. Com o desenvolvimento da ciência, os métodos das ciências naturais e sociais dividiram-se no que diz respeito à abstração. Nas ciências naturais, nas quais os fenômenos do concreto real são representados por objetos ou substâncias físicos ou redutíveis a estes, a abstração mental pode ser substituída, em larga medida, em laboratório, por métodos naturais de purificação dos fenômenos a analisar. Nas ciências da sociedade, porém, onde os fenômenos a analisar consistem basicamente, não em objetos, mas em relações entre os seres humanos, que não podem ser isoladas em laboratório, a abstração mantémse como o principal método, sendo este o caso também da economia política: "... na análise das formas econômicas não podem servir nem o microscópio nem reagentes químicos. A faculdade de abstrair deve substituir ambos" (OCI, p. 12)14. O conjunto de abstratos que representam as essências dos elementos relevantes da totalidade conceitual de um recorte da realidade material, e suas interrelações, são sintetizadas em uma teoria explicativa, o concreto do pensamento ou concreto pensado, que reproduz o real no pensamento, em um processo que vai do abstrato ao concreto do pensamento $\left(A_{b} C_{p}\right)$, oposto à fase anterior (MARX, 1902-03, p. 773). Uma ilustração da importância da concepção da abstração é o fato de que os elementos constituintes do $O$ capital são os abstratos ou conceitos que representam as relações de produção e distribuição vigentes na sociedade capitalista. 


\subsection{O materialismo filosófico e a dialética materialista}

O materialismo dialético, composto pelo materialismo filosófico e a dialética materialista, constitui a base filosófica do marxismo, ou da visão de mundo marxista. Não é possível compreender consistentemente o marxismo desconhecendo, ou mesmo apenas subestimando, um destes elementos.

O materialismo filosófico pode ser definido por uma fórmula simples, como a concepção segundo a qual a realidade material é a única realidade, isto é, "tudo o que existe é apenas matéria ou depende da matéria" (BHASKAR, 1988), não existindo portanto uma realidade extra-matéria ou sobrenatural, pressuposta pelas religiões e pelo idealismo filosófico, expressão refinada daquelas. Porém, esta fórmula simples, embora correta, requer algumas qualificações, referentes aos dois termos - materialismo e matéria -, a fim de que o materialismo filosófico não seja confundido com concepções apenas aparentemente próximas. Como o pensamento constitui uma das esferas da realidade material, cujos fenômenos são também chamados 'espirituais', também se pode dizer que o materialismo filosófico é a corrente filosófica que concebe o mundo material - ou realidade objetiva - como primário, sendo os fenômenos do pensamento dele derivados (ENGELS, s/d, b, p. 178-181; NF 7).

O idealismo filosófico, em frontal contraste com o materialismo, considera primário o mundo espiritual, sendo o mundo material - se considerado existente! - dele derivado. O significado de matéria, porém, não é o mesmo para todos. Segundo cada corrente do idealismo, o mundo material pode, ou não, existir realmente, isto é, independentemente da existência da consciência humana. No entanto, há correntes do idealismo - cujo exemplo extremo é a filosofia do bispo BERKELEY (1685-1753) - que concebem o mundo material como mera ilusão mental, que não existe, portanto, fora da consciência humana.

Uma distinção importante a ser feita é a existente entre o materialismo filosófico e outras formas de materialismo que não incluem o materialismo como filosofia e a concepção materialista da sociedade, portanto ignoram o materialismo histórico. É indispensável, por exemplo, distinguir o materialismo filosófico do realismo, que reconhece a existência de uma realidade objetiva, exterior à consciência. Mas isso é enganoso, pois este mundo exterior pode ser apenas ideal - um mundo de idéias -, como em Platão e seus seguidores (Bergmann, 1926, p. 79). Em síntese, o realismo concebe as idéias como expressão de coisas objetivas existentes fora da consciência e independentemente dela, mas distingue-se do materialismo porque não exclui a existência de uma realidade sobrenatural, uma divindade, etc., que seria também um conjunto de coisas existentes fora da consciência.

É significativo - e exemplo do princípio materialista de que a base material determina a esfera do pensamento, das teorias - o fato de ser o desenvolvimento do materialismo moderno um produto espontâneo do próprio capitalismo, decorrente do espetacular desenvolvimento experimentado pelas ciências naturais na era capitalista (ENGELS, s/d, b, p. 153), como consequência do caráter do desenvolvimento tecnológico como elemento central da concorrência intercapitalista, em especial a partir da revolução industrial do século 18. As exigências da concorrência requerem resultados aplicáveis, na prática, à produção e à circulação do produzido, o que dispensa por completo categorias fantasiosas referentes ao sobrenatural, à magia, a divindades, etc. Este é o motivo pelo qual os cientistas dedicados à 
pesquisa das ciências naturais são materialistas, mesmo que não o declarem ou reconheçam, ou tenham mesmo consciência disto ${ }^{15}$. No entanto, este materialismo é meramente prático, não está baseado em uma concepção filosófica sobre o caráter da existência, ou seja, não se baseia no materialismo filosófico ${ }^{16}$.

Por outro lado, a concepção da própria matéria, como essência do mundo material, está longe de ser consensual, e o seu desenvolvimento foi essencial - e continua sendo - para delimitar com rigor o campo do materialismo filosófico. Embora o conceito de matéria pareça fácil e claro, na realidade não é assim, pois a matéria existe em diferentes formas e pode ser definida, portanto, de diferentes maneiras, sendo, no entanto, mais comumente identificada, no senso comum, com objetos físicos, o que levou, inicialmente, a se identificar 'material' com físico ${ }^{17}$. Devido a isto, fenômenos aparentemente ou realmente não-físicos como, por exemplo, fenômenos descobertos pela física, tais como a radioatividade, as ondas e campos eletromagnéticos, assim como fenômenos mentais, psicológicos, culturais e outros -, deram origem, por parte de filósofos e cientistas não materialistas, ao argumento de que existiam outras realidades além da matéria, concluindo que o materialismo filosófico estaria refutado. No entanto, os fenômenos sucessivamente apresentados como supostamente não-materiais foram reconhecidos, pelo desenvolvimento da ciência, como de natureza comprovadamente material, demonstrando que a matéria apresenta-se sob diversas formas além daquela palpavelmente física. Vê-se, assim, que o rigor do materialismo filosófico depende da precisão do conceito de matéria, e que este deve abarcar todas as suas formas de existência (FATALIEV, p. $91 \mathrm{ss})^{18}$.

Do exposto segue-se que, se a matéria existe sob diversas formas, o conceito filosófico de matéria não pode basear-se em nenhuma das suas formas particulares de existência, mas deve, seguindo o método científico usual da abstração, abranger apenas as características que todas possuem em comum, que, no materialismo, constitui a sua essência (ver seção 2.3). Assim, sendo 'matéria' um abstrato, isto é, produto da abstração, compreende-se a afirmação de Engels, de que "a matéria como tal é uma pura criação da mente, uma abstração" (ENGELS, 1961, p. 217), o que certamente causará espanto em muitos leitores marxistas. Mas em seguida Engels esclarece que a matéria, como conceito abstrato no sentido materialista, isto é, como abstração, não existe como tal, empiricamente: "... a matéria nada mais é que a totalidade das coisas materiais das quais este conceito é abstraído" (Ibidem, p. 200). Assim, sendo a 'matéria' uma figura mental, ela obviamente não pode ser encontrada empiricamente, mas apenas as suas formas concretas de existência, cujo conjunto o conceito 'matéria' representa.

Foi necessário, portanto, elaborar o correspondente conceito abstrato de matéria, que se deve a LENIN, que a definiu como "... categoria filosófica para designar a realidade objetiva, que é dada ao ser humano nas suas sensações, (...) [e que - cmg] exist[e] independentemente delas (LÊNINE, 1982, p. 97) ${ }^{19}$.

A concepção materialista da primazia da matéria sobre o pensamento implica um princípio metodológico segundo o qual um conceito só pode ser considerado verdadeiro se refletir ou representar um fenômeno da realidade objetiva (ver NF28), isto é, se a sua origem e correspondência na realidade material puderem ser comprovadas ${ }^{20}$, uma vez que não há outra origem do pensamento ${ }^{21}$. No caso das ciências humanas, implica também que todos os conceitos referentes a fenômenos sociais surgem somente após os fenômenos que representam terem surgido espontaneamente. Não há outro processo de formação de 
conceitos. Pode-se citar, como exemplos, a divisão do trabalho, que emerge espontaneamente com base em diferenças de idade e sexo no interior dos agrupamentos humanos ou no intercâmbio entre agrupamentos com diferentes hábitos de produção e consumo (OCI/1, p. 277), e, à medida que se estende e aprofunda, penetra gradualmente nas consciências e converte-se no conceito correspondente; o mesmo ocorre com os conceitos de propriedade, escravidão $\operatorname{etc}^{22}$.

A dialética materialista ${ }^{23}$ é o segundo consituinte fundamental do método do marxismo. Se o materialismo filosófico define a matéria, diz o que ela é, a dialética materialista, por sua vez, expõe as características filosóficas do seu processo de existência.

A lógica formal foi elaborada originalmente por Aristóteles e permaneceu essencialmente inalterada até Hegel. Após ter dominado durante toda a Idade Média, a lógica formal aristotélica passou a sofrer "grave descrédito", e isto deveu-se - é essencial constatar - "ao notável desenvolvimento da matemática e da física, a partir do Renascimento", e em seguida da ciência de modo geral, que passaram a exigir novas normas de verdade" (HUISMAN \& VERGEZ, p. 110), tornando obsoleta a lógica discursiva e formalística. Este tipo de lógica adaptava-se ao raciocínio predominantemente especulativo da Antiguidade, baseado no pensamento racional e na argumentação, mas com pouquíssima sustentação em pesquisa científica propriamente dita, praticamente ainda inexistente. A partir do Renascimento, porém, as brilhantes hipóteses filosóficas dos antigos passaram a converter-se em teorias científicas, o que apontou para a necessidade de uma nova lógica (FATALIEV, p. 92). Hegel, finalmente, descartou inteiramente a lógica formal e elaborou a lógica dialética, que era, segundo ele, a lógica propriamente dita24. É esta nova lógica que ele expôs em uma das suas mais importantes obras, "A ciência da lógica", que é a lógica dialética, mas em forma idealista, não materialista.

A dialética, que atingiu sua forma plena com Hegel, substituiu o método de pensamento anterior, metafísico, baseado na imutabilidade e no isolamento recíproco dos objetos e fenômenos da existência, e revolucionou a filosofia, concebendo o mundo como um conjunto não de elementos imutáveis e isolados uns dos outros, mas de processos interligados em uma totalidade e em ininterrupto movimento de transformação (ENGELS, s/d, b, p. 193-8).

Mas a dialética hegeliana era idealista, isto é, baseava-se na concepção da primazia do espírito sobre a matéria, de modo que o movimento do real era concebido apenas como reflexo do movimento do espírito ${ }^{25}$. A despeito disto, na opinião de Marx, apesar da "mistificação que a dialética sofreu nas mãos de Hegel, [isto - cmg] de modo algum impede que ele tenha sido o primeiro a expor as suas formas gerais de movimento de maneira abrangente e consciente" (OCI, 1983, p. 20; DKI, p. 12).

Por outro lado, Hegel associou à dialética uma nova, e decisiva, concepção do movimento - o automovimento ou movimento dialético. A forma mais simples do movimento 26 - e a primeira a ser reconhecida - foi o movimento mecânico, isto é, o deslocamento dos corpos no espaço, associado, por exemplo, ao materialismo mecanicista do século 18. Esta forma de movimento resulta da ação recíproca entre os corpos e tem, portanto, uma causa externa e não altera a natureza dos corpos. O movimento dialético, ao contrário, é a mudança que tem sua origem na dinâmica das contradições residentes no interior dos próprios objetos ou fenômenos e altera a sua natureza. Novamente, porém, para Hegel o automovimento é 
uma propriedade das ideias, que são, para ele, a realidade concreta, cujo movimento os objetos reais apenas refletem.

Marx e Engels tomaram de Hegel o elemento revolucionário da sua filosofia - a dialética e "o enorme sentido histórico" que a acompanhava (ENGELS, 1974, p. 194) - mas descartaram a sua forma idealista ${ }^{27}$, e atribuíram o automovimento aos próprios objetos materiais. Assim, para o materialismo, o movimento é a própria forma de existência da matéria ${ }^{28}$. A relevância deste princípio pode ser ilustrada, por exemplo, por constituir a essência do objetivo de Marx ao elaborar $O$ capital: "... a finalidade última desta obra é descobrir a lei econômica do movimento da sociedade moderna ..." (DKI, p. 3; OCI, p. 13). Mas o movimento, ou a transformação, resulta da dinâmica das contradições internas constituintes de todas as formas e manifestações da matéria. Assim, a integração da dialética ao materialismo, por Marx e Engels, constitui a dialética materialista.

Como a contradição e o automovimento dela resultante são características inerentes à matéria, a explicação de um objeto ou fenômeno, tomados como processos, consiste em explicar o seu automovimento a partir das suas contradições internas ${ }^{29}$, que remete a uma categoria fundamental da dialética, que são as leis de movimento dos fenômenos, que expressam a relação entre as contradições e o movimento delas decorrente.

Uma implicação decisiva das leis da dialética, apesar de contestada no próprio campo marxista, consiste na direção do movimento, da mudança, que não é aleatória, mas progressiva, isto é, o real movese, como regra geral, de formas mais simples a mais complexas ${ }^{30}$ (ENGELS, s/d, b, p. 173 e passim), o que se traduz na lei da negação da negação, e pode ser observado tanto na natureza, quanto na sociedade e no pensamento ${ }^{31}$.

Sendo assim, a pesquisa materialista tem por objetivo descobrir as leis que presidem o processo de existência do objeto ou fenômeno, suas leis de movimento. A lei científica é o enunciado ou conjunto de enunciados que expõem e explicam o movimento do objeto ou fenômeno pesquisado ${ }^{32}$. A simples descrição de um objeto ou fenômeno, com abstração do seu movimento, expõe a sua estrutura e revela as suas partes constituintes, enquanto a lei expõe o seu processo de existência, isto é, explica o seu movimento ou processo de evolução e transformação, objeto da dialética.

Para Hegel, segundo a concepção idealista, as leis da dialética eram leis do pensamento, leis ideais, como a própria realidade. Para M/E, ao contrário, estas leis, assim como qualquer idéia ou conceito, eram deduzidas da realidade material ${ }^{33}$, por intermédio das leis de movimento do próprio pensamento, que é uma das esferas da matéria ${ }^{34}$. Estas leis constituem características da realidade material e, como tais, convertemse em elementos do método (ver seção 3, introd). Como o pensamento também é um produto da matéria, as suas formas e leis são também, do mesmo modo que nas demais formas da matéria, expressões das características objetivas do cérebro e do seu produto, o pensamento, que são aos poucos desvendadas pelo desenvolvimento do conhecimento humano. A lógica formal, ao contrário, tem a pretensão de que as leis da lógica são recursos elaborados pela mente, independentemente da realidade objetiva, a fim de compreendê-la, ou seja, a lógica ensinaria a pensar. O fato de serem leis formais, isto é, referentes à forma dos argumentos, implica que são indiferentes ao conteúdo ${ }^{35}$. A propósito disto, Lênin cita a "penetrante 
observação [de Hegel - cmg] sobre a lógica: 'é uma noção preconcebida', que [a lógica - cmg] 'ensina a pensar' (do mesmo modo que a fisiologia 'ensina' a digerir??)" (Lenin, 1986, p. 77)

Prado Jr, abordando o mesmo tema, afirma certeiramente: "Não é ... possível ditar regras ao pensamento, no sentido da lógica metafísica, 'legislar' para ele como faz ... a lógica formal clássica ... tanto quanto não é possível 'legislar' para outras funções orgânicas", e acrescenta: "Com a sucessão e repetição dos processos de pensamento (a sucessão de homens e gerações que pensam), desenvolve-se também (...) a formalização de tal processo" (PRADO JR, 1955, p. 565; ENGELS, 1978a, p. 14/1976, p. 13) ${ }^{37}$. A extensão temporal e a espontaneidade do desenvolvimento destes métodos do conhecimento ocultam a sua origem e induzem aqueles que finalmente os reconhecem a concebê-los como criação puramente espiritual ${ }^{38}$. O idealismo e a lógica formal procedem, neste caso, do modo expresso pelo lapidar dito de Marx: "depois de tirar do mundo real a categoria (...), tira-se dessa categoria o mundo real" (MARX E ENGELS, A sagrada família, apud PRADO JR., idem, p. 525) ${ }^{39}$.

É comum encontrar-se críticas à exposição, considerada deficiente, de Engels (ALTHUSSER, 1979, p. 115), no Anti-Dühring, sobre a dialética e suas leis. Mas Engels estendeu-se mais sobre este tema em outra obra, dedicada especificamente ao mesmo, A dialética da natureza. Como só foi publicada em 1925 (ENGELS, 1961), autores relevantes do marxismo, que opinaram sobre o tema antes desta última data (como Lenin, desaparecido em 1924, e também Lukács, em História e consciência de classe ${ }^{40}$, obra publicada em 1923), só dispunham do Anti-Dühring como referência. Também se questionou o número de leis citadas por Engels. Como já se indicou, Marx e Engels tomaram as leis da dialética de Hegel ${ }^{41}$, e o seguiram na concepção da existência de três leis fundamentais, que Hegel formulou e fundamentou extensamente na Ciência da Lógica ${ }^{42}$. Seria de esperar que os críticos contestassem teoricamente, de modo consistente, esta fundamentação. Prado Jr possui o mérito de tê-lo intentado, embora sem sucesso (PRADO JR, 1955, p. 527-537). Seja como for, a simples formulação destas leis, na forma materialista, como orientadoras do pesquisador, pode ser considerado um passo revolucionário (ALTHUSSER, 1979, p. 112) em relação às concepções em que se baseiam a lógica formal e a metafísica, uma vez que aquelas leis dão suporte ao conceito fundamental do movimento dialético como estado ou forma de existência da matéria.

Marx utiliza-se amplamente destas leis na exposição de O capital, geralmente implícitas na argumentação, sem citá-las diretamente, o que obriga o leitor de $O$ capital a conhecê-las e levá-las em consideração, a fim de reconhecê-las tal como utilizadas por Marx. Alguns exemplos ilustrativos disto e da coincidência da opinião de Marx e Engels a este respeito são apontados a seguir. A lei da transformação de mudanças quantitativas em mudança qualitativa, a respeito da qual Engels foi bastante preciso ${ }^{43}$, é aplicada por Marx à economia, apontando a sua aplicação igualmente às ciências naturais:

O possuidor de dinheiro ou de mercadorias só se transforma realmente em capitalista quando a soma mínima adiantada para a produção ultrapassa de muito o máximo medieval. Aqui, como nas ciências naturais, comprova-se a exatidão da lei descoberta por Hegel, em sua Lógica, de que modificações meramente quantitativas em certo ponto se transformam em diferenças qualitativas". Em nota de rodapé Marx acrescenta: "A teoria molecular aplicada pela Química moderna ... não se baseia em outra lei (MARX, 1981, p. 273; 1983, p. 243, itálicos acrescentados). 
Marx também utiliza as leis da negação da negação: "... a produção capitalista produz, com a inexorabilidade de um processo natural, sua própria negação. É a negação da negação" (DKI, p.705/ OC1/2, p. 294); e da unidade e luta dos contrários: "Na vida econômica atual encontra[-se - cmg] não só a concorrência e o monopólio, mas também a sua síntese, que não é uma fórmula, mas um movimento. $\mathrm{O}$ monopólio produz a concorrência, a concorrência produz o monopólio" (MARX, 1974c, p. 27); "logo, a produção é imediatamente consumo e o consumo é imediatamente produção. Cada um é imediatamente o seu contrário" (MARX, 2011a, p. 46).

A tendenciosidade das opiniões sobre Engels pode ser ilustrada por uma crítica comum, referente ao seu exemplo sobre as implicações dialéticas do movimento mecânico: um corpo em movimento entre os pontos A e B já não se encontra inteiramente no ponto A, mas também ainda não se encontra inteiramente no ponto B, ou encontra-se nos dois pontos ao mesmo tempo. Considera-se 'óbvio' que o corpo ou está em A ou está em $\mathrm{B}^{44}$. Os críticos parecem desconhecer não só o fato de o exemplo ser do próprio Hegel, como de este ter respondido lapidarmente à crítica, de que também foi alvo: a representação do movimento pela localização sucessiva em dois pontos, como A e B, não é representação do movimento, mas do resultado do movimento. O movimento deveria ser a representação do processo de deslocamento do corpo de um ponto a outro, que implica que não se encontra em um nem no outro, mas em ambos ao mesmo tempo. Elementos de demonstração deste enunciado já estão disponíveis, hoje, na matemática avançada, segundo Lawvere, membro de um grupo da matemática de fronteira:

The characterization of motion as the presence of the same body in two places at the same time is only an irresolvable contradiction if we ignore that the metaphysical opposition between points and neighborhoods (...) is not maintained in the practice even of mathematics (LAWVERE, p. 136).

Além disso, uma evidência factual, sobre a posição de um corpo em dois lugares ao mesmo tempo, surgiu na Física quântica - segundo relato de Cox e Forshaw, comparecendo como título do capítulo 2 da sua obra, "Estar em dois lugares ao mesmo tempo" -, baseada nos resultados de experimento fundamental de Davisson e Germer, em 192745.

Finalmente, há uma tendência de se dar destaque à oposição entre a dialética e a lógica formal, deixando em segundo plano a oposição à metafísica. No entanto, se a dialética se opõe de modo absoluto à metafísica, a sua oposição à lógica formal é apenas relativa, uma vez que, segundo Engels, a dialética a incorpora. Para a pesquisa marxista as críticas ao estilo metafísico e à lógica formal são ambas indispensáveis, mas de naturezas diferentes ${ }^{46}$. A incorporação crítica da lógica formal ao materialismo dialético justifica-se porque, como já argumentado, as leis da lógica formal, como todas as leis do pensamento, não são invenções arbitrárias destinadas a 'ensinar a pensar', como a própria lógica formal crê, mas leis objetivas do pensamento, apenas sistematizadas tardiamente, principalmente por Aristóteles (PRADO JR, 1981, p. 32ss; ver NF36 e texto correspondente).

\subsection{Do abstrato ao concreto do pensamento, e retorno deste ao concreto real - método teórico e método aplicado}


Os escritos de Marx e Engels sobre o método referem-se ao processo de apropriação da realidade objetiva pelo pensamento, ou seja, de formulação da teoria que explica determinado objeto ou fenômeno da realidade, por intermédio do método $C_{k} A_{b} C_{p}$, que denominaremos método teórico ${ }^{47}$, por tratar-se do método de elaboração das teorias. Marx divide o método, assim concebido, em duas fases, como já exposto. São as fases de análise $C_{\mu} A_{b}$ (decomposição da realidade analisada em suas partes constituintes) e de síntese $A_{b} C_{p}$ (recomposição da realidade, no pensamento, através da agregação das partes separadas) ${ }^{48,49}$. É significativo que, para Marx, é esta segunda fase que constitui "o método cientificamente correto" (MARX, 1902-3, p. 773), pois o resultado desta fase é a teoria, a explicação do objeto estudado, que é o objetivo da pesquisa científica.

Deve-se notar que o problema focalizado por Marx é o da elaboração de uma teoria, mas não do uso ou da aplicação da teoria. Ou seja, a exposição de Marx detém-se na teoria que foi elaborada pelo pensamento. Mas a teoria, representada pelo concreto do pensamento, por sua vez, torna-se um guia para a ação, isto é, para a atividade prática, que é o problema que aqui se pretende examinar. Para esta exposição é necessário esclarecer o sentido do concreto $^{50}$. O $C_{p}$ não é o $C_{r}$, isto é, o empírico, mas uma síntese ou agregação, no pensamento, dos abstratos ou conceitos que representam os elementos essenciais do $C_{r}$ no pensamento. Ou seja, o $C_{p}$, ou teoria, ainda é uma representação abstrata do real.

O pesquisador marxista, porém, não se detém na teoria, mas tem um passo a dar após atingí-la, que consiste em aplicá-la à realidade empírica, e esta passagem requer, também, um método, que aqui se denominará método aplicado. Entende-se aqui, por aplicação da teoria, a atividade do pesquisador cujo objetivo é explicar uma forma de existência empírica que a teoria representa no plano abstrato. O método aplicado consiste em localizar, na realidade empírica, os elementos correspondentes aos conceitos abstratos e suas interconexões, assim como o movimento do real analisado, como expressão empírica da lei abstrata de movimento do objeto, isto é, o seu processo de evolução (LANGE, p.114-138). Por exemplo, a teoria do capitalismo, exposta no $O$ capital, é uma construção abstrata, cujos elementos são os conceitos ou "categorias econômicas, [que] são apenas abstrações [ou 'expressões abstratas ideais', p. 28] das relações reais" (MARX, 1974c, p. 26; 1978, p. 121, 199; RUBIN, p.58,), que representa, portanto, a essência do capitalismo mas não representa um capitalismo específico realmente existente. A teoria do capitalismo foi elaborada por Marx e encontra-se exposta no $O$ capital, que é, portanto, um concreto do pensamento, isto é, a reconstrução do objeto pesquisado - o capitalismo - no e pelo pensamento. Não é necessário, portanto, repetir o percurso de Marx, do concreto real $C_{r}$ ao concreto do pensamento $C_{p}$. O pesquisador, ao contrário, deve dar um passo além daqueles expostos por Marx. Este passo consiste em reencontrar na realidade material o segmento que corresponde, no concreto real, ao concreto do pensamento ou teoria de que está fazendo uso.

A teoria do capitalismo, elaborada por Marx, permite ao pesquisador atual compreender os capitalismos reais e neles atuar. Ao estudar uma economia capitalista real, a teoria do capitalismo é o guia que lhe indica as categorias e leis que deve procurar, e onde procurá-las. Ao fazê-lo, o pesquisador defrontase com uma dificuldade, apontada por Marx, que consiste em que o caminho do abstrato ao concreto é mais difícil do que do concreto ao abstrato ${ }^{51}$, o que se deve ao fato de ser a teoria uma construção composta por 
abstratos, que consistem nas essências dos objetos realmente existentes. Estes, no entanto, expõem à observação não a sua essência, mas a sua aparência, que geralmente mascara a essência. Daí resulta que o pesquisador vê-se diante de um cipoal de aparências, no interior do qual deve localizar os elementos reais correspondentes aos conceitos da sua teoria.

Dois requisitos são fundamentais para a eficácia do método aplicado: em primeiro lugar, o pesquisador deve conhecer suficiente e detalhadamente o método teórico acima exposto e a teoria do fenômeno que está pesquisando, e que, no caso do capitalismo, é a teoria de O capital e das obras de marxistas que a complementaram; em segundo lugar, deve estudar e conhecer também suficiente e detalhadamente as características do fenômeno empírico que, no caso do capitalismo, é a economia capitalista que está sendo pesquisada. O método aplicado consiste, portanto, em utilizar a teoria que explica um fenômeno como guia para encontrar, na manifestação real do fenômeno que está sendo analisado, os componentes e suas conexões, indicados pela teoria.

\section{Os grandes ramos do método. As grandes divisões da matéria e dos ramos do conhecimento}

\subsection{Introdução}

O mundo material pode ser dividido, para fins analíticos, das mais diversas maneiras, dependendo da finalidade de cada pesquisa. No entanto, há também uma divisão que não depende da finalidade da pesquisa, mas das diferentes naturezas qualitativas das diferentes esferas da matéria. Assim, segundo a sua natureza, a matéria pode ser dividida, em primeira aproximação, em Natureza, Sociedade e Pensamento. Os grandes ramos do conhecimento humano, que acompanham a divisão da realidade material segundo as suas diferentes naturezas, são basicamente as ciências naturais, as ciências sociais ou humanas, tomadas como sinônimos, e a filosofia. As três distinguem-se pelo fato de que, nas ciências naturais e sociais o objeto do conhecimento são os objetos e fenômenos da realidade externa à consciência, ao passo que, na filosofia, o objeto do conhecimento é o próprio processo de conhecimento ${ }^{52}$. O materialismo filosófico e a dialética materialista, aplicados ás ciências naturais, podem ser denominados - seguindo Engels - dialética da Natureza (MARX E ENGELS, 1974a, p. 182, 190; MARX, 1977b, p. 30), cujo método não é objeto do presente artigo.

A divisão da matéria tem implicações sobre o método. Com base no exposto até aqui o materialismo dialético pode ser considerado uma teoria do existente ${ }^{53}$, representado na mente humana no mais elevado nível de abstração. No entanto, descendo um degrau na escala da abstração, o pesquisador já não se depara com 'a' matéria, que, como abstrato que é, só existe como tal no pensamento, mas depara-se com as suas infinitas formas objetivas qualitativamente diferentes, organizadas, porém, em grandes agrupamentos segundo identidades fundamentais. A explicação do existente, contida no materialismo dialético, deve ser, portanto, individualizada para as diferentes esferas particulares da matéria. A reflexão sobre o existente reduz, novamente, as formas particulares da matéria, neste primeiro degrau de 
concretização, aos conceitos que representam as suas três grandes esferas, que são, como já exposto, a Natureza, a Sociedade e o Pensamento.

É nesta fase que o materialismo dialético se converte de teoria em método ${ }^{54}$, pois são as leis gerais de movimento do materialismo dialético, convertidas em elementos de método ${ }^{55}$, que orientam a descoberta das leis de movimento específicas de cada uma das grandes esferas da matéria, no primeiro degrau da escala da abstração. A representação abstrata de cada uma destas formas da matéria contém as suas leis de movimento, e, quando suficientemente desenvolvida, constituem um concreto do pensamento, síntese do diverso, ou seja, uma teoria. Marx e Engels desenvolveram com profundidade apenas a teoria da Sociedade ${ }^{56}$, que é o materialismo histórico, uma explicação do movimento histórico da sociedade. Por esre motivo, a exposição da continuidade do processo de diferenciação da matéria e, correspondentemente, do método, será ilustrada com a diferenciação do materialismo histórico.

Antes de prosseguir, deve-se notar que se abriu caminho a uma conclusão da maior importância: se as teorias explicativas dos grandes ramos da matéria são elaboradas com base nos princípios do materialismo filosófico e da dialética materialista (cujo exemplo concreto é o materialismo histórico), consubstanciados numa teoria do existente, o materialismo dialético, convertido em método, segue-se que cada uma destas teorias constitui apenas uma particularização do materialismo dialético no primeiro nível da abstração. Deve-se concluir, necessariamente, que o materialismo dialético constitui o método propriamente dito do marxismo e, consequentemente, como se demonstrará, constitui o método da economia política, apenas particularizado através de uma sucessão de níveis de abstração decrescente ou de concretização crescente. É o próprio Marx que o afirma, como se mostrará na seção referente ao método da economia política.

Como toda teoria, o materialismo histórico é também uma representação abstrata do seu objeto, a sociedade, portanto, uma categoria do pensamento. A sociedade existe, porém, em diversas formas particulares, qualitativamente diferentes uma da outra. $\mathrm{O}$ materialismo histórico, portanto, não representa nenhuma forma particular da sociedade. As formas particulares da sociedade tornam-se objetos de pesquisa no segundo degrau da escala da abstração. Para tanto, a teoria do materialismo histórico converte-se, por sua vez, em método para o estudo das formas particulares da sociedade e seu desenvolvimento. Embora o materialismo e a dialética estejam incorporados à teoria do materialismo histórico, não são dispensáveis como referências explícitas neste estudo ${ }^{57}$. Portanto, o método do materialismo histórico compõe-se do método do materialismo dialético e da teoria do materialismo histórico, convertida em método. As leis mais gerais de movimento da sociedade convertem-se em leis do método necessário para estudar as formas particulares assumidas pela mesma em diferentes épocas históricas e diferentes regiões na mesma época ${ }^{58}$.

No estudo das formas particulares da sociedade, o pesquisador defronta-se com a sociedade em cada uma das suas formas concretas de existência, os modos de produção, como por exemplo o feudal ou o capitalista. A fim de identificar os degraus da teoria e do método, necessários para explicar um modo de produção particular, é oportuno apelar para o procedimento de Marx ao desenvolver, n'O capital, a teoria geral do capitalismo. Manifestamente, os elementos gerais de método necessários são uma teoria geral dos modos de produção e uma teoria geral da transição entre modos de produção. Esta divisão é mais formal 
do que real, uma vez que, em uma perspectiva dialética, é impossível desenvolver uma destas teorias isoladamente. Conceber o modo de produção dialeticamente significa concebê-lo não como uma figura estática, repetindo-se continuamente, mas como um elo na cadeia histórica dos modos de produção. Consequentemente, a transição, que é o seu movimento dialético, está implícita no conceito do modo de produção. No entanto, uma vez desenvolvida a teoria geral dos modos de produção, é possível isolar os elementos abstratos fundamentais da transição a fim de elaborar uma teoria geral da transição, útil para o estudo das transições.

Portanto, o resultado da pesquisa neste degrau da escala da abstração consiste em duas teorias paralelas: as teorias gerais dos modos de produção e da transição, respectivamente, fundamentos das teorias gerais dos modos de produção particulares, como a teoria geral do capitalismo, contida n'O capital.

\subsection{O materialismo histórico ou concepção materialista da história}

\subsubsection{O método do materialismo histórico59}

Os métodos de pesquisa dos ramos particulares da realidade - como o materialismo histórico e a dialética da natureza, assim como suas subdivisões - compreendem tanto o uso do método teórico quanto do aplicado. O método é o teórico sempre que se trate da formulação de teorias gerais, que seguem a sequência 'concreto real-abstrato-concreto pensado' - $C_{p} A_{b} C_{p}-$, e o aplicado sempre que se trate da utilização de uma teoria geral como guia para a pesquisa de situações concretas, como seria o caso da utilização da teoria geral da transição entre o feudalismo e o capitalismo como guia para analisar uma transição concreta, como, por exemplo, entre o feudalismo e o capitalismo na Alemanha, ou o caso já citado da teoria d'O capital como guia para a pesquisa de um capitalismo particular, por exemplo, o brasileiro. Por outro lado, nas subdivisões da matéria, o método teórico incorpora como conceitos e leis do método os conceitos e leis de movimento dos níveis superiores àquele submetido à pesquisa, por exemplo, o método teórico de Marx, ao elaborar $O$ capital, engloba, além do materialismo filosófico e da dialética materialista, também os conceitos e leis gerais do materialismo histórico e das teorias gerais dos modos de produção e da transição, como por exemplo, os conceitos de trabalho social, de propriedade, de forças produtivas e relações de produção, etc, assim como as leis da determinação das RP pelas FP e da contradição entre ambas, etc.

No presente artigo apresenta-se as teorias correspondentes às subdivisões do materialismo histórico, em uma sequência descendente, das teorias gerais às dos modos de produção concretos, como se cada uma derivasse logicamente da anterior. Na realidade, porém, elas deveriam ser apresentadas na ordem inversa, dos modos de produção particulares concretos, na base, às teorias gerais, o que decorre naturalmente do princípio da abstração, isto é, as teorias gerais dos modos de produção particulares, como as do escravismo ou do feudalismo, são obtidas, através de generalização ou abstração crescente, a partir da análise dos modos de produção particulares concretos, isto é, das diversas economias escravistas ou feudais, respectivamente ${ }^{60}$; e a partir do conjunto das teorias gerais dos diversos modos de produção particulares, se 
obteria a teoria geral dos modos de produção. O mesmo aplica-se às teorias da transição entre modos de produção ${ }^{61}$. Ou seja, a exposição desenvolve-se em sentido inverso ao da pesquisa, mas isso apenas ilustra a necessária diferença entre os métodos de pesquisa e de exposição ${ }^{62}$, invocada por Marx para esclarecer o caráter d'O capital, já mencionada na NF3. Assim, na pesquisa, uma teoria geral dos modos de produção só pode ser elaborada depois que os modos de produção particulares tiverem sido explicados, ou seja, o conhecimento de cada um tenha passado pela fase $C_{k} A_{b}$, a fim de permitir a generalização e as sínteses representadas pelo concreto do pensamento. Mas aqui trata-se não da pesquisa, mas da exposição dos resultados. Pode-se acrescentar, para maior esclarecimento que, segundo o método $C_{p} A_{b} C_{p}$, a pesquisa parte de $C_{r}$, que vai do particular para o geral, enquanto a exposição parte de $C_{p}$, do geral para o particular, como no ponto em exame. Marx acrescenta que, caso a pesquisa seja bem sucedida, e "a vida [o movimento real - $\mathrm{cmg}$ ] do objeto refletir-se no plano das ideias [e, consequentemente, na exposição - cmg], pode parecer que nos defrontamos com uma construção a prior" (DKI, p. 12, tradução livre - cmg).

O materialismo histórico, na condição de estudo dos fenômenos da sociedade, com base na utilização dos princípios do materialismo filosófico e da dialética materialista na pesquisa dos fenômenos da sociedade, incorpora todos os princípios de ambos, já expostos. Assim, na análise da matéria social vigoram os princípios de que a base material determina os fenômenos sociais, segundo a citação de Marx, expsta acima; de que a sociedade, como esfera da matéria, segundo a definição desta, e seus componentes, encontram-se em permanente movimento, tal como expresso nas leis gerais da dialética; de que, consequentemente, a explicação dos fenômenos sociais requer a identificação das suas leis de movimento; de que estas leis não são leis do pensamento, mas constituem-se espontaneamente no processo de constituição da sociedade em cada uma das suas formas históricas, e são extraídas das mesmas por meio da pesquisa metódica do seu movimento, na qual vigora o princípio de que o pensamento não cria a realidade, mas apenas a expressa ou reflete idealmente.

Nesta esfera é onde mais facilmente o pesquisador corre o risco de desviar-se dos princípios materialistas, não só devido ao domínio absoluto do idealismo filosófico na sociedade atual, mas também porque o próprio pesquisador materialista é confundido pela ilusão de que é o pensamento que produz a realidade - porque pode imaginar que os conceitos (abstrações), com os quais opera, e que não possuem existência empírica como tais, nascem da sua própria cabeça - ao passo que apenas a re-produz, como teoria abstrata, única forma pela qual o ser humano a compreende (MARX, 1978, p. 121; 2011b, p. 54-5).

$\mathrm{Na}$ sociedade a matéria pesquisada é constituída pelos fenômenos sociais, que são fenômenos materiais, emanações da matéria socialmente organizada. Neste sentido, compreender uma esfera da realidade material implica identificar a sua estrutura e leis de movimento, de que é exemplo o objetivo declarado de Marx na sua análise do capitalismo, como já indicado.

Desde a revolução científica que caracterizou o Renascimento, as ciências naturais obedecem ao princípio materialista de que o seu propósito é descobrir as leis objetivas que presidem os fenômenos analisados, leis que devem a sua existência unicamente às características da estrutura da matéria (ENGELS, s/d, a, p. 285-292), sem qualquer interferência de elementos de intencionalidade humana e menos ainda extra-humana. É um mérito inegável de Marx e Engels o fato de terem estendido este princípio fundamental 
à explicação dos fenômenos da sociedade, o que significa que, segundo a sua concepção, o objetivo das ciências da sociedade é descobrir as leis objetivas que presidem os fenômenos sociais pesquisados ${ }^{63}$.

Um aspecto crucial para a compreensão do caráter científico do materialismo histórico é o reconhecimento de que o que distingue a concepção das leis sociais em Marx e Engels é que lhes atribuem a mesma característica impositiva das leis naturais, diferindo, porém, no fato de que as leis sociais mudam com os modos de produção ${ }^{64}$, enquanto as leis naturais são eternas (o que Engels, no entanto, convincentemente coloca em dúvida e limita ao nosso planeta [ENGELS, 1961, p. 202]). Em diversas passagens das suas obras filosóficas, ambos referem-se às leis que presidem os fenômenos sociais como leis que operam com a mesma força irreprimível, ou com a mesma férrea necessidade, das leis naturais ${ }^{65}$, o que significa, precisamente, que o movimento evolutivo da sociedade não é determinado por iniciativas intencionais dos seres humanos, mas por leis impessoais e geralmente não percebidas, que independem de o ser humano ter delas consciência, mas o impelem a agir do modo que age. Assim como as leis naturais emanam não de um ente sobrenatural mas das características objetivas da estrutura da própria matéria natural, as leis sociais emanam das características objetivas da estrutura da matéria social, ou seja, as leis de movimento de todas as formas da matéria - sendo a sociedade uma delas - possuem caráter objetivo, não subjetivo. Os críticos deste princípio não percebem que negá-lo implica negar o caráter científico, ou seja, a objetividade, das ciências sociais.

Disto segue-se que, embora o ser humano seja o autor ou produtor da sua própria existência e da sua própria história, ele as produz sem premeditação e sem ter consciência dos efeitos da sua ação e do próprio fato de ser a sua ação a causa do desenvolvimento histórico (GERMER, 2009). Isto começa a mudar com a emergência do materialismo histórico, que identifica as leis objetivas que movem a sociedade mas não as abole.

\subsubsection{Conceitos fundamentais}

Como o ser humano produz a sua própria história sem ter disto consciência - que é a condição da objetividade das ciências da sociedade -, é preciso identificar a motivação objetiva que o força, compulsoriamente e de modo sistemático, a uma ação da qual resultam, impremeditadamente, a sociedade e sua evolução histórica. Esta ação decisiva, no nível mais abstrato, é o trabalho, e a motivação fundamental - instintiva - é a obtenção dos meios necessários à sobrevivência, que é, pela sua própria natureza, ininterrupta. Como, ademais, o trabalho está na origem de todas as características essenciais da sociedade (MARX E ENGELS, 1975, passim), segue-se que ele constitui a atividade prática fundamental e a causa não intencional de todo o desenvolvimento histórico (Ibidem, p.37).

No entanto, os seres humanos não trabalham isoladamente, mas cooperam no trabalho, o que dá origem a uma -rede de relações entre os indivíduos e à divisão social do trabalho, que é um elemento das forças produtivas, convertendo, por um lado, o conceito simples de trabalho no conceito de trabalho social (ibidem), base econômica do conceito materialista de sociedade. 
O trabalho organizado deste modo é condicionado, em cada época histórica, por uma forma particular da propriedade dos meios de produção, dando origem às relações de produção, que, nas sociedades divididas em classes, são relações de classes, isto é, entre as classes de proprietários e nãoproprietários. Estas relações necessárias formam uma rede ou sistema de relações sociais ${ }^{66}$, que constitui a sociedade ${ }^{67}$, conceito fundamental do materialismo histórico.

As leis da dialética aplicam-se igualmente à pesquisa da sociedade:, pois esta, como parte do mundo material tem, no movimento dialético, um elemento constituinte fundamental da sua forma de existência. O que determina o movimento da sociedade são as contradições a ela inerentes e que, nos modos de produção baseados na propriedade privada, são contradições entre os interesses opostos das classes sociais - que conduzem à luta de classes - e cujo fundamento material é a contradição entre o desenvolvimento das forças produtivas e o sistema vigente de relações de produção, ou, em outras palavras, "... entre o desenvolvimento material da produção e sua forma social" (OCIII/2, p. 315).

Do princípio materialista de que o pensamento apenas reproduz a realidade material, decorre o princípio metodológico segundo o qual, "o modo de produção da vida material condiciona o processo em geral de vida, social, político e espiritual. Não é a consciência dos homens que determina o seu ser, mas, ao contrário, é o seu ser social que determina sua consciência" (MARX E ENGELS, 1975, p. 25-8; MARX, 1974a, p. 136). Ou seja, é a rede específica de relações de produção, em que os indivíduos estão mergulhados, em cada modo de produção, que determina a sua consciência, isto é, a superestrutura jurídica, política, etc assim como os seus componentes ideológicos, culturais e assim por diante. Assim, a pesquisa social, com base no materialismo histórico, consiste em identificar os elementos desta rede de relações, que constitui a estrutura econômica da sociedade e o objeto da ciência econômica materialista.

Entre os conceitos fundamentais específicos da ciência da sociedade foram já mencionados os conceitos de trabalho social, ser social e consciência social, de forças produtivas e relações de produção, de base e superestrutura, de divisão social do trabalho, de propriedade dos meios de produção, de classes sociais e diversos outros. A emergência da propriedade privada dos meios de produção, resultado espontâneo do desenvolvimento das forças produtivas, constitui um momento decisivo da evolução histórica da sociedade, porque dá origem, no campo teórico, à propriedade como conceito jurídico e, na esfera material, à divisão da sociedade em classes, inaugurando o longo período dos modos de produção baseados na propriedade privada. Todos estes conceitos convergem para o conceito fundamental de modo de produção.

Dois princípios relevantes do materialismo histórico, referentes ao papel das forças produtivas são: o primeiro afirma que as relações de produção são determinadas pelo grau de desenvolvimento atingido pelas forças produtivas, e alteram-se qualitativamente à medida que as forças produtivas experimentam o mesmo tipo de mudança ${ }^{68}$. Este tema é crucial para o materialismo histórico, pois implica atribuir ao desenvolvimento das forças produtivas, como expressão do desenvolvimento do trabalho social, o papel determinante do desenvolvimento social e da sucessão de modos de produção. É este, efetivamente, o ponto de vista de Marx: as forças produtivas "são a base de toda a sua [do ser humano - cmg] história" (MARX, 1974c). Este princípio, que possui sólido caráter materialista (GERMER 2009), é contestado por muitos marxistas $^{69}$ (por exemplo, BETTELHEIM, p. 31-7). O segundo princípio relevante é o papel especial 
desempenhado pelos meios de trabalho, por constituírem o elemento diferenciador das épocas econômicas ${ }^{70}$ (OCI/1, cap. 5).

O automovimento histórico da sociedade materializa-se na sucessão de modos de produção, o que determina a existência de dois campos de pesquisa, que, embora interligados, podem ser separados para fins de pesquisa: o referente às leis de movimento próprias a cada modo de produção, e o referente às leis que presidem a transição de um modo de produção a outro, dando origem às teorias gerais dos modos de produção e da transição, respectivamente ${ }^{71}$. As elaborações de Marx e Engels sobre ambos os temas não são teorias detalhadas, mas fornecem os elementos e relações essenciais das suas estruturas. Por outro lado, os conhecimentos sobre os modos de produção passados - exceto o feudal, mais conhecido -, são ainda fragmentários e comumente interpretados a partir de olhares idealistas. Os esboços de teorias deixados por Marx e Engels devem, no entanto, necessariamente, integrar a exposição do 'método da economia política', uma vez que constituem elementos essenciais da estruturação teórica de $O$ capital, sem os quais este não pode ser adequadamente compreendido.

\subsubsection{A teoria geral dos modos de produção}

Os modos de produção são as fases "historicamente determinadas" (DKI, p. 55/OCI, p. 73), qualitativamente diferentes umas das outras, que caracterizam o desenvolvimento da sociedade humana. Uma teoria geral dos modos de produção é possível, segundo a teoria de Marx, porque todos eles possuem características gerais comuns, que s obtém através da abstração das suas particularidades diferenciadoras ${ }^{72}$.

Cada modo de produção constitui uma combinação contraditória de determinado nível de desenvolvimento das forças produtivas com as relações de produção correspondentes, determinadas ${ }^{73}$ por aquelas $^{74}$. Esta definição enuncia corretamente o conceito, mas a sua simplicidade permite que seja repetido mesmo sem ser entendido ${ }^{75}$. Deve-se, portanto, analisar os dois termos da definição, apresentando, ao mesmo tempo, a fundamentação da plausibilidade e da necessidade de uma teoria geral dos modos de produção, também contestada por críticos marxistas e não-marxistas (p. ex. Jessop, p. 291).

As forças produtivas estão claramente definidas por Marx (OCI, cap. 5), e a sua relevância decorre não apenas de serem determinantes das relações de produção ${ }^{76}$ - lei fundamental do desenvolvimento social, repetida incansavelmente por Marx ao longo de toda a sua obra -, mas também condicionantes da continuidade histórica na sucessão dos modos de produção ${ }^{77}$. A importância ímpar atribuída por Marx às forças produtivas, no desenvolvimento da sociedade, pode ser avaliada pela sua afirmação de que constituem nada menos que "a base de toda sua história" (1974c, p. 21).

As forças produtivas constituem a base técnica do modo de produção, enquanto as relações de produção constituem sua base econômica, o seu elemento propriamente social. Eis como Marx as define:

$\mathrm{Na}$ produção social da própria vida, os homens contraem relaçôes determinadas, necessárias e independentes de sua vontade, relações de produção estas que correspondem a uma etapa determinada de desenvolvimento das suas forças produtivas materiais. A totalidade dessas relações de produção forma a estrutura econômica da sociedade, a base real sobre 
a qual se levanta a superestrutura jurídica e política e à qual correspondem determinadas formas

de consciência social (MARX, 1974e, p. 135, itálicos acrescentados) 78 .

Portanto, as relações de produção ${ }^{79}$ são as relações sociais - isto é, relações entre os indivíduos na produção social - no interior das quais a produção se desenvolve, condicionadas, no essencial, pela forma vigente da propriedade. Nas sociedades baseadas na propriedade privada, o núcleo central de tais relações é constituído pelas relações entre proprietários e não-proprietários.

Para maior clareza da teoria das relações de produção de Marx, e do seu caráter materialista e dialético, é conveniente distinguir as três formas em que estas relações são apresentadas: em primeiro lugar na realidade objetiva, como relações materiais, situação própria ao uso da expressão relações de produção, como constituintes objetivos da estrutura econômica da sociedade; em segundo lugar na forma jurídica, na qual as relações de produção expressam-se nas leis da propriedade, sancionando juridicamente a forma dominante da propriedade em cada modo de produção (MARX, 1980, p. 100; 1981, p. 60; 1977a, p. 130); finalmente, no plano teórico, na forma das categorias teóricas da economia política - ou categorias econômicas -, como expressões abstratas das relações de produção objetivas.

Do ponto de vista do método, observe-se a utilização, por um lado, do princípio materialista da primazia da matéria (as relações de produção) sobre o pensamento (as categorias econômicas): as relações de produção são fenômenos objetivos que se expressam, na mente, na forma de abstrações, conceitos; e, por outro, da dialética, no movimento histórico das relações de produção com base na contradição entre elas as forças produtivas.

\subsubsection{A teoria geral da transição entre modos de produção}

Como toda matéria, a matéria social - a sociedade - move-se, isto é, transforma-se ao longo da história, e este movimento histórico explica-se com base nas leis dialéticas gerais, já expostas. Cada modo de produção segue uma sequência de fases: nascimento, desenvolvimento, auge e declínio. Esta última fase caracteriza-se pelo início da emergência de elementos do novo modo de produção ${ }^{80}$. A sequência das fases é determinada pela lei de movimento do modo de produção, que coloca em evidência a natureza e as tendências de cada modo de produção. Finalmente, a evolução da relação entre os dois elementos básicos do modo de produção, FP e RP, determina a dinâmica interna deste, colocando ambos em contradição crescente, que se expressa na contradição de classes e desemboca nas lutas de classes responsáveis pela transição a novo modo de produção.

As leis que presidem a transição entre modos de produção têm o mesmo caráter de todas as leis que expressam o movimento imanente da matéria, isto é, são leis objetivas e operam com a força de leis naturais. Referindo-se ao capitalismo, diz Marx que "a produção capitalista gera, com a inexorabilidade de um processo natural, sua própria negação" (DKI, p. 705; OCI/2, p. 294). No prefácio à Contribuição à crítica da economia política (MARX, 1974e), Marx sistematiza a essência da teoria da transição, que desenvolveu desde os primeiros escritos próprios e em conjunto com Engels.

Com base na definição do modo de produção, pode-se definir a transição entre modos de produção, inicialmente de modo esquemático, como a transformação da forma vigente da relação entre 
forças produtivas e relações de produção (FP/RP) em uma nova forma da mesma relação, o que implica a emergência de uma nova estrutura de classes a partir da estrutura de classes vigente. A nova relação FP/RP é mais avançada, caracterizada por forças produtivas mais desenvolvidas e, correspondentemente, uma produtividade média do trabalho significativamente superior à da sociedade no interior da qual brotou, o que significa que a sucessão de modos de produção é progressiva ${ }^{81}$. Esta conclusão pode ser observada historicamente e demonstrada teoricamente, e ao mesmo tempo metodologicamente, com base na lei dialética geral da passagem de formas mais simples a formas mais complexas de desenvolvimento da matéria, a lei da negação da negação. As objeções a esta conclusão referem-se, geralmente, à ocorrência de retrocessos localizados, mas que não desmentem a tendência geral observada na história da sociedade humana.

A mudança da relação FP/RP é causada pelo desenvolvimento progressivo das forças produtivas. Mudando as forças produtivas, mudam correspondentemente as relações de produção ${ }^{82}$, o que significa que se altera a forma da propriedade e, consequentemente, mudam as relações entre os indivíduos na sociedade, que se baseiam naquela ${ }^{83}$. Surgem, portanto, novas classes sociais, em substituição às anteriores. A nova forma da propriedade cristaliza-se em forma jurídica, que assegura e protege institucionalmente o poder econômico da classe proprietária. A contradição básica do modo de produção é a que se estabelece entre as forças produtivas, que continuam desenvolvendo-se, e a forma da propriedade, imobilizada na forma jurídica ${ }^{84}$. À medida que o desenvolvimento das forças produtivas as afasta, progressivamente, das relações de produção vigentes, embriões do novo modo de produção surgem e se desenvolvem, e a sua identificação permite vizualisar a configuração do novo modo de produção.

Também neste caso deve-se fazer distinção entre a teoria geral, ou abstrata, exposta, da transição entre modos de produção, e as teorias, também gerais ou abstratas, das transições particulares, como por exemplo, a teoria da transição entre o feudalismo e o capitalismo. A teoria geral da transição entre modos de produção refere-se às características gerais de toda transição entre modos de produção, independentemente de qual transição se trate, seja, por exemplo, a transição entre o escravismo e o feudalismo, ou entre o capitalismo e o socialismo. A teoria geral de uma transição particular seria, por exemplo, a teoria geral da transição entre o feudalismo e o capitalismo. Outra coisa é o estudo de uma transição particular concreta, já não como teoria geral ou abstrata, mas como estudo de uma transição concreta, por exemplo, entre o feudalismo e o capitalismo na Inglaterra. Neste caso trata-se da utilização do método aplicado, isto é, não de elaborar a teoria, mas de determinar as características empíricas da transição, na Inglaterra, correspondentes às categorias teóricas expostas na teoria geral da transição entre o feudalismo e o capitalismo.

\subsubsection{O método teórico geral de pesquisa dos modos de produção particulares}

Trata-se da elaboração da teoria geral de um modo de produção particular, ao qual pertence $O$ capital, sob o título de 'economia política'. A economia política deve ser entendida, no marxismo, em dois sentidos. O primeiro como teoria econômica (burguesa) do capitalismo. Foi nesta qualidade, com efeito, que a economia política se desenvolveu historicamente, paralelamente ao desenvolvimento do próprio 
capitalismo. Mas Engels, no Anti-Dühring, conferiu-lhe, por generalização, um sentido mais amplo, como "ciência das leis que regem a produção e o intercâmbio dos meios materiais da vida na sociedade humana" $\left(\right.$ ENGELS, 1976, p. 127) ${ }^{85}$. Nesta qualidade, a economia política constituiria a teoria mais geral, ou abstrata, da base econômica dos modos de produção, concretizando-se como teoria geral da base econômica de cada modo de produção particular - por exemplo, O capital em relação ao capitalismo - e como teoria específica de cada economia concreta de um modo de produção - por exemplo, o capitalismo na Inglaterra.

O método teórico de elaboração da teoria geral de um modo de produção particular, pode ser representado pela agregação de algumas afirmações metodológicas de Marx no prefácio à $1^{a}$ ed de O capital, omitindo, no entanto, para generalizar, as referências ao capitalismo. Marx afirma propor-se a "... pesquisar ... o modo de produção ... e as suas relações correspondentes de produção e de circulação", com "... a finalidade... [de] descobrir a lei econômica do movimento da sociedade ...", ou seja, "a lei natural do seu movimento", o que significa que se "concebe o desenvolvimento da formação econômica da sociedade como um processo histórico-natural". E acrescenta: "... não se trata do grau mais elevado ou mais baixo de desenvolvimento dos antagonismos sociais que decorrem das leis naturais da produção ... . Aqui se trata dessas leis mesmo, dessas tendências que atuam e se impõem com necessidade férrea" (OCI, p. 12).

Duas indicações metodológicas de Marx merecem menção. A primeira é que, "na teoria, se pressupõe que as leis do modo de produção (...) atuem em sua forma pura [o que está implícito no princípio da abstração - cmg]. Na realidade, há sempre aproximação ..." (OCIII/1, p. 136). A segunda: para melhor entender um fenômeno, deve-se analisá-lo na sua forma mais desenvolvida, por isso a Inglaterra é a fonte principal de ilustração de O capital (OCI/1, p. 12).

\subsubsection{O método da economia política - ou método de pesquisa do modo de produção capitalista -O capital}

O desenvolvimento desta pesquisa conduziu à conclusão de que método propriamente dito de Marx e Engels é o materialismo dialético, ou seja, combinação do materialismo filosófico com a dialética materialista. Esta é a caracterização completa do método de Marx e Engels. Sendo assim, é também o 'método da economia política', ou seja, d'O capital. É o próprio Marx quem o diz, apontando explicitamente, no Posfácio à $2^{a}$ edição de OCI, a "fundamentação materialista do ... método" e o "método dialético" d'O capital (OCI, p.19 e 20, respectivamente), aos quais acrescenta, no prefácio à $1^{a}$ ed. a técnica a abstração (Ib, p. 12). Marx não se refere, como feito no presente artigo, aos elementos da teoria do materialismo histórico que se convertem em elementos do método para o estudo dos níveis mais concretos, como a teoria geral dos modos de produção e a teoria do capitalismo. Implicitamente os incorpora ao materialismo dialético, com o que coincide, na essência, a conclusão já alcançada neste artigo.

Como se pode observar revendo o texto do artigo em retrospectiva, há um longo percurso entre o método teórico geral do materialismo dialético e o método da economia política, que é o método teórico 
de estudo do capitalismo e, mais ainda, o método aplicado do mesmo estudo. Apesar desta distância metodológica, o 'método teórico da economia política' abarca, como princípios metodológicos, todas as leis de desenvolvimento expostas nas sucessivas seções do artigo. Este método começa com a concepção materialista, isto é, da realidade material como única realidade, que é reproduzida no pensamento na forma de teorias, e focaliza a realidade com base nos princípios da dialética materialista, que implica que a matéria, neste caso a matéria social, é intrinsecamente dinâmica, transforma-se, seguindo, sob formas particulares, as leis gerais da dialética materialista. $\mathrm{O}$ 'método da economia política' é um capítulo do materialismo histórico, aplicação do materialismo dialético ao estudo da sociedade, e incorpora portanto os princípios e pressupostos gerais do materialismo dialético e dos níveis sucessivos do materialismo histórico, aos quais acrescenta, ao final, aqueles específicos ao próprio capitalismo. Como capítulo do materialismo histórico, o 'método da economia política' pressupõe a existência de diferentes modos de produção ao longo da história, cuja sucessão expressa uma forma do movimento da matéria social, que é a transição de um modo de produção ao seguinte, em sucessão progressiva, e o movimento interno de cada modo de produção, que o conduz do nascimento ao declínio e à transformação em novo modo de produção.

$\mathrm{N}^{\prime} O$ capital estão presentes todos os componentes do método materialista e dialético, complementados pelo método da abstração, altamente valorizado por Marx. O materialismo filosófico está presente na concepção do objeto - a estrutura econômica do capitalismo - como recorte do mundo material, especificamente a sociedade humana. Esta consiste na matéria consciente (o ser humano), organizada socialmente, sujeita a leis de desenvolvimento objetivas e independentes da vontade humana, isto é, às quais o ser humano está submetido, que ele pode conhecer, através da pesquisa, e pode utilizar para seus fins mas não pode abolir. Está presente a concepção materialista da precedência da matéria sobre o pensamento, o que significa que as idéias têm sua origem na realidade material e existem como representação mental de aspectos da realidade material. Esta, portanto, precede o pensamento.

A dialética materialista está presente na concepção da sociedade como um recorte da realidade, não um recorte estático, mas em movimento ininterrupto, como ocorre com toda a matéria. O movimento da sociedade materializa-se no seu caráter histórico, isto é, transitório, expresso na sucessão dos modos de produção, que são progressivos, no sentido de que cada modo de produção é superior ao que o precedeu, e desenvolve-se no sentido da sua própria superação por novo modo de produção, também superior a ele próprio. O movimento dialético da sociedade capitalista significa que é um movimento originado endogenamente com base nas contradições internas, expressas na lei econômica do seu movimento, cuja descoberta constituiu o objetivo d'O capital. Este objetivo Marx atinge por intermédio do estudo dos elementos constituintes da economia capitalista, que são as relações de produção e distribuição próprias desta economia, e cujo conjunto constitui a expressão da propriedade privada capitalista dos meios de produção.

\section{Considerações finais}


Diversas conclusões foram alcançadas ao longo do artigo. Nesta seção se apontará apenas as que podem ser consideradas mais relevantes:

1) a primeira e mais importante é que o método propriamente dito de Marx e Engels, é o materialismo dialético (expressão utilizada pela primeira vez por Plekhanov em 1891), combinação do materialismo filosófico com a dialética materialista. Talvez se objete que isto é óbvio, mas muito genérico. Se é óbvio, por que há dúvida quanto ao método d'O capital? O detalhamento deve ser procurado nas obras dos grandes autores, nas quais Marx e Engels se apoiaram, e nos seus próprios inúmeros escritos referentes ao método. Além disso, a omissão da consulta às obras filosóficas e metodológicas de Engels parece ser um dos obstáculos ao entendimento mais detalhado e aprofundado do método de Marx;

2) o mesmo é explicitamente afirmado por Marx sobre o método da economia política.

2) a pesquisa permitiu constatar, nesta primeira aproximação, a coincidência dos pontos de vista de Marx e Engels, no que diz respeito aos temas de método, em todos os momentos em que Marx a eles se refere, o que sugere que as obras filosóficas e metodológicas de Engels, na sua fase final, expõem as concepções comuns a ele e a Marx;

3) Marx e Engels atribuíram uma importância extraordinária à abstração, como método ou técnica de pesquisa, merecedora de menção especial no prefácio à $1^{a}$ edição d'OCI, algumas de cujas implicações filosóficas foram apontadas. Surpreendem as escassas referências, no mais das vezes ausentes, a esta técnica nas obras sobre o método de Marx e Engels;

4) a análise mais aprofundada da distinção, apontada por Marx, entre os modos de pesquisa e de exposição revelou o possível simplismo da concepção de que o 'método d'O capital' está contido nesta obra;

5) a inclusão do método denominado aplicado, como parte do método da economia política apresenta-se como complemento indispensável ao pesquisador marxista da economia contemporânea, nos seus esforços para compreender a dinâmica do capitalismo e, principalmente, a emergência dos elementos do novo modo de produção, o comunismo, que se anunciam nas entranhas do capitalismo, algumas já apontadas por Marx;

\section{Referências}

ALTHUSSER, L. Filosofia e filosofia espontânea dos cientistas. Lisboa : Presença, 1976.

ALTHUSSER, L. Sobre a relação de Marx com Hegel. In: D'HONDT, J. (Org.) (1979). Hegel e o Pensamento Moderno. Porto : RÉS Editora, p. 109-138, 1979.

ANDERSON, P. Considerações sobre o marxismo ocidental. Porto, Portugal : Afrontamento, 1976

BERGMANN, E. Einführung in die Philosophie. Erster Band: Erkenntnisproblem. Breslau : Ferdinand Hirt, 1926.

BETTELHEIM, C. A Luta de Classes na União Soviética; Primeiro Período (1917-1923). Rio de Janeiro : Paz e Terra, 1976.

BHASKAR, R. Materialismo. In: BOTTOMORE, T. (Ed.) Dicionário do pensamento marxista. 2a. ed. Rio de Janeiro : Jorge Zahar, p. 254-8, 1988.

BURKETT, J.P. Marx's concept of an economic law of motion. History of Political Economy 32.2 (2000) 381-394, 1998. 
BURKETT, P. Lukács on Science: A New Act in the Tragedy. Historical Materialism 21.3 (2013) 3-15, 2013.

COMEY, D.D. Lógica. In: LOBKOWICZ, N. (Org.) (1975). Marxismo y Democracia : Filosofía. Tomo 4. Madrid : Rioduero., p. 47-67, 1975.

COX, B. \& FORSHAW, J. O universo quântico : tudo que pode acontecer realmente acontece. São Paulo : Fundamento Educacional, 2016.

CHUPAJIN, I.I. Teoría del concepto. Buenos Aires : Nuestro Tiempo, 1964.

ENGELS, F. Karl Marx "Zur Kritik der politischen Ökonomie". Rezension II. In: MARX, K. et ENGELS, F. (1974a), p. 188-202, 1974.

ENGELS, F. Anti-Dühring. Rio de Janeiro : Paz e Terra, 1976.

ENGELS, F. Herrn Eugen Dührings Umwälzung der Wissenschaft (“Anti-Dühring”). Berlin : Dietz Verlag. In: MARX, K. / ENGELS, F. (1978). Werke, Band 20, p. 1-303, 1978 a.

ENGELS, F. Dialéctica de la naturaleza. México D.F. : Grijalbo, 1961.

ENGELS, F. Do socialismo utópico ao socialismo científico. In: MARX, K. e ENGELS, F. (s/d, a), p. 281-336, 2/d, a.

ENGELS, F. Ludwig Feuerbach e o fim da filosofia clássica alemã. In: MARX, K. e ENGELS, F. (s/d, b), p. 169-207, s/d, b.

ENGELS, F. und MARX, K. Die Heilige Familie oder Kritik der kritischen Kritik : gegen Bruno Bauer und Konsorten. Berlin : Dietz Verlag, 1973.

FATALIEV, Kh. O Materialismo Dialético e as Ciências da Natureza. Rio de Janeiro : Zahar, 1966.

GERMER, C.M. A relação abstrato/concreto no método da economia política. In: Corazza, G. (Org.).

Métodos da ciência econômica. Porto Alegre : Editora da UFRGS, 2003.

GERMER, C.M. Marx e o papel determinante das forças produtivas na evolução social. Crítica Marxista, IFCH, Unicamp, Campinas, n. 29, 2009, p. 75-95, 2009.

GERMER, C.M. A concepção das relações de produção na teoria do capitalismo. Artigo aceito no XXV Encontro Nacional de Economia Política, da SEP - Sociedade Brasileira de Economia Política, 2020 .

GORSKI, D.P. Objeto y significado de la lógica. In: GORSKI, D.P. y TAVANTS, P.V. (Orgs.) (1965). Lógica. 2a . Ed. México, D.F. : Grijalbo, p. 11-37, 1965.

HEGEL, G.W.F. Wissenschaft der Logik I, Erster Teil: Die objektive Logik, Erstes Buch. 2. Aufl. Frankfurt am Main : Suhrkamp Verlag, 1990.

HEGEL, G.W.F. Introdução à história da filosofia. In: HEGEL, G.W.F. Hegel : v.II. 4a. ed. São Paulo : Nova Cultural, p. 81-158, 1989.

HEGEL, G.W.F. Enzyklopädie der philosophischen Wissenschaften im Grundrisse. In: HEGEL, G.W.F. (1979). HEGEL, G.W.F. Werke. Band 8, Frankfurt a. M. 1979, S. 41-65.

http://www.zeno.org/Philosophie/M/Hegel, +Georg+Wilhelm+Friedrich/Enzyklop \%C3\%A4die+der+ philosophischen + Wissenschaften $+\mathrm{im}+$ Grundrisse, 1979.

ILIÉNKOV, E.V. La lógica económica del socialismo. Quito, Ecuador : ER Edithor, 2012.

INWOOD, M. Dicionário Hegel. Rio de Janeiro : Jorge Zahar, 1997.

KANT, I. Lógica. Rio de Janeiro : Tempo Brasileiro, 1992.

LABICA, G. As “Teses sobre Feuerbach” de Karl Marx. Rio de Janeiro : Jorge Zahar Editor, 1990.

LANGE, O. Moderna Economia Política: Problemas Gerais. 2a. ed. Rio de Janeiro : Fundo de Cultura, 1967.

LAPP, R.E. (Org.) A matéria. Rio de Janeiro : José Olímpio, 1973.

LENIN, V.I. Cuadernos filosóficos. Obras completas, t. 29. Moscú : Progreso, 1986.

LÉNINE, V.I. Materialismo e Empiriocriticismo. Moscovo : Progresso / Lisboa : "Avante!", 1982. 
LUKÁCS, G. Sociologia / organizador José Paulo Netto. São Paulo : Ática, 1981.

MARX, K. O método da economia política. In: MARX, K. Manuscritos Econômico-Filosóficos e

Outros Textos Escolhidos. São Paulo : Abril Cultural, p. 122-9, 1974a.

MARX, K. Marx an Joseph Dietzgen. In: Karl Marx / Friedrich Engels. Werke (MEW), v. 32. Berlin : Dietz Verlag. [https://marxwirklichstudieren.files.wordpress.com/2012/11/mew_band32.pdf], 1974b.

MARX, K. Carta a Annenkov, de 28 de dezembro de 1846. In: MARX, K. e ENGELS, F. Cartas sobre E1 Capital. 2a. ed. Barcelona : Editorial Laia, p. 20-31, 1974c.

MARX, K. Carta de Marx a Kugelmann, de 11/7/1868. In: MARX, K. e ENGELS, F. (1974b), p. 179181, 1974d.

MARX, K. Para a crítica da economia política. In: MARX, K. Manuscritos Econômico-Filosóficos e Outros Textos Escolhidos. São Paulo : Abril Cultural, p. 107-263, 1974e.

MARX, K. Die Methode der politischen Ökonomie. [Electronic ed.]. In: Die neue Zeit : Wochenschrift der deutschen Sozialdemokratie. - 21.1902-1903, 1. Bd.(1903), H. 23, S. 772-9.

[http://library.fes.de/nz/], 1902-3.

MARX, K. Teses sobre Feuerbach. In: MARX, K. e ENGELS, F. (s/d, b). Obras Escolhidas. v. 3. São Paulo : Editora Alfa-Omega, p. 208-210, s/d, b.

MARX, K. Die Methode der politischen Ökonomie. In: MARX, K. Ökonomische Manuskripte

1857/58. Text - Teil 1. (Grundrisse I). Berlin : Dietz Verlag. Karl Marx Friedrich Engels Gesamtausgabe (MEGA), II/1.1, p. 35-43, 1976.

MARX, K. Das Elend der Philosophie : Antwort auf Proudhons "Philosophie des Elends". Berlin : Dietz Verlag. In: K. MARX / F. ENGELS. Werke, Band 4, 1977 a.

MARX, K. Elementos Fundamentales para la Crítica de la Economia Politica (Borrador) 18571858. v. 1, 9a. ed. México, Siglo xxi Argentina Editores, 1977b.

MARX, K. Miséria da Filosofia. Lisboa : Editorial Estampa, 1978.

MARX, K. Das Kapital, Band I / Mit einem Geleitwort von Karl Korsch. Frankfurt/M : Ullstein Materialien, 1981.

MARX, K. Das Kapital, Band III. Frankfurt/M : Ullstein, 1980.

MARX, K. O Capital, v. I/1. São Paulo : Abril Cultural, 1983.

MARX, K. O Capital, v. I/2. São Paulo : Abril Cultural, 1984.

MARX, K. O Capital. v. III/2. São Paulo : Abril Cultural, 1985.

MARX, K. Grundrisse. São Paulo : Boitempo ; Rio de Janeiro : Ed. UFRJ, 2011a.

MARX, K. O método da economia política. In: MARX, K. (2011a), p. 54-61, 2011b.

MARX, K. et ENGELS, F. Textes Sur la Méthode de la Science Économique / Texte Über die Methode der Ökonomischen Wissenschaft. Édition bilingue. Paris : Éditions Sociales, 1974a.

MARX, K. e ENGELS, F. Cartas sobre El Capital. 2a. ed. Barcelona : Editorial Laia. 1974b.

MARX, K. e ENGELS, F. Feuerbach: A Oposição entre as Concepções Materialista e Idealista (Cap. I de A Ideologia Alemã). Lisboa : Editorial Estampa, 1975.

MARX, K. e ENGELS, F. Cartas sobre las ciencias de la naturaleza y las matemáticas. Barcelona : Anagrama, 1975.

MARX, K. e ENGELS, F. Obras Escolhidas em 3 vol. Vol. 2. São Paulo : Editora Alfa-Omega, s/d,a. MARX, K. e ENGELS, F. Obras Escolhidas em 3 vol. Vol. 3. São Paulo : Editora Alfa-Omega, s/d,b. MELIUJIN, S. El problema de lo finito y lo infinito. México : Grijalbo, 1960.

MOSER, P.K. and TROUT, J.D. (Eds.) Contemporary materialism : a reader. London : Routledge, 1995.

NETTO, J.P. Introdução ao estudo do método de Marx. São Paulo : Expressão Popular, 2011. 
PRADO JR, C. Dialética do conhecimento. 2 v. $2^{\text {a }}$ ed. São Paulo : Brasiliense, 1955.

PRADO JR, C. O que é filosofia. In: Primeiros Passos, v. 6. São Paulo : Círculo do Livro, p.9-62, 1981.

RUBIN, I.I. A Teoria Marxista do Valor. São Paulo : Brasiliense, 1980.

SARTRE, J.-P. et al. Marxismo e existencialismo : controvérsia sobre a dialética. Rio de Janeiro : Tempo Brasileiro, 1966.

WETTER, G.A. Filosofia e ciências da natureza na União Soviética. Lisboa : Livros do Brasil, 1963.

Notas

${ }^{1}$ Este artigo constitui um desenvolvimento de artigo apresentado no XXIII Encontro Nacional de Economia Política, da Sociedade Brasileira de Economia Política, 12-15 de junho de 2018.

${ }^{2}$ Claus Magno Germer, Doutor, Professor Associado IV, aposentado, do Dep. de Economia da Universidade Federal do Paraná, Curitiba (PR), Currículo Lattes http://lattes.cnpq.br/0765931181351363, email: cmgermer@ufpr.br.

${ }^{3}$ Melhor examinado, o problema parece não ter solução tão simples. Qual é a lógica d'O capital? Marx, ao abordar o seu método, no posfácio à $2^{a}$ ed alemã de DKI (p.12), afirmou que o "modo da exposição deve distinguir-se formalmente do modo da pesquisa". Ora, $O$ capital é uma exposição, não um relatório de pesquisa, o que parece significar que o método d'O capital não é o da pesquisa, mas o da exposição, o que implica que não se pode extrair o método de pesquisa de Marx d'O capital. O feliz enunciado de Netto aponta para uma diferença marcante entre ambas: "os pontos de partida são opostos: na investigação ... parte de perguntas ...; na exposição ... parte dos resultados que obteve na investigação" [Netto, p. 27, itálicos acrescentados]. Uma diferença adicional será apontada adiante (seçao 3.2.1).

${ }^{4}$ Este texto de Marx, que faz parte de um texto maior sobre diversos problemas de método (Marx et Engels, 1974a; Marx, 190203), não é o único escrito de Marx sobre o tema. Outro é a seção 2, O segredo da construção especulativa, do capítulo 5 de $A$ sagrada Familia (Engels \& Marx, 1973). Também em A miséria da filosofia a seção 1 do cap. 2 intitula-se O método (Marx, 1977a). O cap. 1 da Ideologia alemãa, assim como o Prefácio à Contribuição à crítica da economia política e a carta a Annenkov (Marx \& Engels, 1974, p. 20-31), são obviamente textos metodológicos. Contribuições adicionais indispensáveis encontram-se no prefácio à $1^{\mathrm{a}}$ e no posfácio à $2^{\mathrm{a}}$ edições alemãs de OCI e em outros textos menores, e nos escritos filosóficos de Engels (Engels, s/d, b; 1976; 1961; s/d, a).

${ }^{5}$ Inicialmente pretendeu-se utilizar a expressão materialismo naturalista, mas como esta aparece com sentido dúbio nas referências encontradas, e como Engels utilizou a expressão dialética da Natureza, para o mesmo fim, preferiu-se optar também por esta última expressão.

6 "O defeito fundamental de todo materialismo anterior ... está em que só concebe o objeto, a realidade, o ato sensorial, sob a forma do objeto ou da percepção, mas não como atividade sensorial humana, como prática, ... " (Marx, s/d, p. 208; Labica, 1990, p. 21).

7 "(...) para mim (...) o ideal [isto é, as idéias, pensamentos - cmg] nada mais é que o material transposto e traduzido na mente humana" (Marx, OCI/1, p. 20). Segundo Inwood, para Hegel "(...) as leis da Natureza não são proposições formuladas por nós mas fatos objetivos, que podemos descobrir mas cujos limites não podemos transpor (...)" (Inwood, p. 203).

8 A importância atribuída por Marx e Engels à abstração, ilustrada pelos escritos que a ela dedicaram, justificaria um tratamento mais detalhado do tema, impossível no presente artigo, mas que pode ser encontrado, em parte, em Germer, 2003, e em Germer, 2020, na qual a presente seção se apóia.

9 Os principais textos, localizados nesta pesquisa, em que a abstração é exposta são: Engels und Marx, 1973, cap. 5.2; Marx, 1978, p. 116-21; 1974a; Engels, 1961, passim; além de diversas passagens breves e menções.

${ }^{10}$ Nos textos analisados Marx e Engels utilizam o mesmo termo, abstração, para designar tanto o método como seu produto, aqui denominado o abstrato, o que parece mais esclarecedor.

11 "... todas as coisas, em última abstração, ... se apresentam no estado de categorias lógicas" (Marx, 1978, p. 118).

${ }^{12}$ Como abstração, o trabalho reduz-se a "(...) um mero fantasma: "o" trabalho (...) não é nada mais que uma abstração e, considerado em si, nem sequer existe" (Marx, 1985, p. 270 ; DKIII, 1980, p. 761).

13 Engels também sugeriu que o próprio conceito monoteista moderno de um deus incorpóreo resultou da progressiva abstração das características essenciais dos numerosos deuses, de diferentes povos, que se sucederam ao longo do tempo (Engels, s/d, b, p. 189). Pelo critério de Marx, portanto, deus, como abstração, é também um "mero fantasma, que, considerado em si, nem sequer existe".

${ }^{14}$ Para maior comodidade do leitor, as citações d'O capital e de Das Kapital são referidas apenas às iniciais da obra seguidas do volume em romanos.

15 "O materialismo é atualmente a ontologia sistemática dominante entre filósofos e cientistas, e no momento não há abordagens ontológicas alternativas competindo com ele" (MOSER and TROUT, p. ix).

16 Althusser sugere a existência de uma "filosofia espontânea dos cientistas", composta por dois elementos contraditórios: um elemento materialista, expressão da prática materialista da pesquisa, dominado porém por um elemento idealista, exterior ao ambiente da pesquisa (Althusser, 1976, p. 125-151), que é a ideologia burguesa dominante.

17 A ciência não-marxista ainda se debatia com este problema pelo menos até a década de 1970: "... a principal meta dos cientistas permanece inalterada. (...) eles estão ainda buscando a resposta básica para o que é a matéria" (ver Lapp, p. 9-11). 
18 A delimitação precisa do conceito de matéria e sua aplicação a todos os fenômenos da existência não tem sido um processo pacífico, mas estabeleceu-se graças a uma incansável e contínua luta teórica, que prossegue, entre cientistas e filósofos materialistas e idealistas desde o século 19, de que são exemplos Fataliev e Meliujin (1960) no campo materialista, no século 20.

19 Eis como Wetter aborda esta evolução no marxismo: "(...) Engels ... era materialista porque concebia a matéria como realidade fundamental e única. Podem-se considerar conceitos como imagens das coisas e, apesar disso, aceitar-se uma realidade espiritual, independente da matéria". Segundo o mesmo autor, a primeira parte do conceito de matéria de Lênin, como tudo o que existe fora e independentemente da conscência, é compatível com a existência de "um ser espiritual, que seria, a um tempo, realidade objetiva, existente fora da nossa consciência", porém acrescenta: "Lênin estreita o conceito de 'realidade' para o que atua sobre os nossos órgãos sensoriais e mostra assim ser um verdadeiro materialista" (Wetter, p. 22, 24).

20 Para o materialismo, o critério da verdade é a prática, isto é, o critério para considerar verdadeira uma proposição sobre a realidade é a sua eficácia na aplicação prática (Engels, s/d, b, p. 180; Lênin, 1982).

21 Isto não exclui a elaboração de conceitos a partir de conceitos preexistentes acumulados, originados na realidade material. "La utilización de los conocimientos adquiridos con anterioridad y comprobados en la práctica nos exime de comprobar directamente todo pensamiento. Al analizar el contenido de estos conocimentos anteriores y al relacionar con él los nuevos hechos captados, podemos inferir un nuevo conocimiento sin recurrir a la experiencia directa" (Gorski, p. 13). Também não exclui a combinação de conceitos sobre objetos reais a fim de construir representações da realidade que não correspondem a quaisquer situações reais, como são, por exemplo, as obras de ficção artística - literatura, cinema, etc -, as ideologias religiosas, etc, inclusive as hipóteses científicas, enquanto não comprovadas.

22 Eis uma passagem ilustrativa da utilização coerente deste princípio por Marx: "A cooperação baseada na divisão do trabalho ou a manufatura é nos seus inícios uma formação desenvolvida espontaneamente. Tão logo ela tenha ganho alguma consistência e amplitude de existência, torna-se a forma consciente, planejada e sistemática do modo de produção capitalista" (OCI/1, p. 285), ou seja, após desenvolver-se espontaneamente, o fenômeno real dá origem ao conceito que o representa.

23 Embora seja comum, ao referir-se à dialética, não se acrescentar o adjetivo 'materialista', não é irrelevante fazê-lo, uma vez que existe uma dialética idealista, desenvolvida de Kant a Hegel (Engels, s/d, b, p. 193-198), do qual Marx e Engels tomaram o conceito e, nas palavras do próprio, colocaram-no de pé, uma vez que encontrava-se de cabeça para baixo.

24 "Hegel se opuso a la lógica formal com desprecio (...). Para Hegel, la lógica verdadera es la dialéctica, no la formal, y la lógica dialéctica es la más fundamental de todas las ciencias" (Comey, p. 54).

$25 \mathrm{Na}$ maneira de ver hegeliana, "... o homem nada mais é que o instrumento do qual a ideia ou a razão eterna se serve para desenvolver-se" (Marx, 1974c,p. 23)

${ }^{26}$ Embora simples, possui importantes implicações, quando analisada dialeticamete, como indicado adiante.

27 "Para Hegel, o processo de pensamento, que ele, sob o nome de idéia, transforma num sujeito autônomo, é o demiurgo do real, real que constitui apenas a sua manifestação externa. Para mim, pelo contrário, o ideal não é nada mais que o material, transposto e traduzido na cabeça do ser humano" (OCI/1, p. 20; DKI, p. 12). Esta é a razão de Marx afirmar que colocou de pé a dialética, que, em Hegel, estava de cabeça para baixo.

28 "Tudo o que existe, tudo o que vive sobre a terra e sob a água, não existe, não vive senão por um movimento qualquer. Assim, o movimento da história produz as relações sociais (...)" (Marx, 1978, p. 118). "O movimento é o modo de existência da matéria. Nunca, em parte alguma, existiu, nem pode existir, matéria sem movimento" (Engels, 1976, p. 51), o que foi amplamente confirmado, por exemplo, no próprio âmago da matéria, pelo desenvolvimento da Física nuclear no século 20.

29 "O que constitui o movimemto dialético é a coexistência de dois lados contraditórios, a sua luta e a sua fusão numa nova categoria" (Marx, 1978, p. 125). Por exemplo, "... se se deseja avaliar corretamente a produção feudal, deve-se encará-la como um modo de produção baseado na contradição" (Marx, 1977a, p. 140; 1978, p. 135).

30 "... na história, assim como no seu reflexo literário, o desenvolvimento, de modo geral, também vai desenvolvimento também vai das relações mais simples às mais complexas ..." (Engels, 1974, p. 196).

31 Althusser destoa da crítica frequente a Stálin, acusado de ter omitido a lei da negação da negação, considerada, por Althusser, responsável pelo componente teleológico da filosofia de Hegel: "Stalin pode ser considerado um filósofo marxista perspicaz ... por ter riscado a negação da negação das "leis" da dialética" (Althusser, 1979, p. 132). Engels, porém, considera esta última a "lei fundamental para a construção de todo o sistema" da Ciência da Lógica (NF 40), e Marx não só não a negou, como a utilizou em seus escritos.

32 Segundo Hegel, "... uma lei (...) descreve o auto-movimento, ao invés do movimento imprimido do exterior. O auto-movimento é necessário, enquanto [o segundo - cmg] (...) é contingente, no sentido de que o primeiro expressa a natureza da entidade que se move, enquanto o segundo não o faz" (Burkett, 1998).

33 "As leis da dialética são ... extraídas da história da natureza, assim como da história da sociedade humana. Elas não são, com efeito, nada mais do que as leis gerais destas duas fases do desenvolvimento histórico, assim como do próprio pensamento. (...) [Todas - cmg] foram desenvolvidas por Hegel, no seu estilo idealista, como simples leis do pensamento. O erro [de Hegel - cmg] consiste em que essas leis, como leis do pensamento, são impostas à natureza e à história, ao invés de serem deduzidas destas" (Engels, 1961, p. 41).

34 Em uma definição sintética, "a dialética nada mais é que a ciência das leis gerais de movimento e desenvolvimento da natureza, da sociedade humana e do pensamento" (Engels, 1978a, p. 131-2/1976, p. 120), que constituem as três grandes esferas da matéria. "(...) o processo do pensamento (...) é também um processo da natureza, (...) [e] pode diferenciar-se só gradualmente, (...) conforme a maturidade do órgão que serve para pensar" (Marx, 1974d, p. 181). A filosofia grega "... parte do pressuposto inconsciente de que também o pensamento seja o ser" (Hegel, 1989, p. 151).

$35 " . .$. as regras universais e necessárias do pensamento em geral só podem concernir à forma, de modo nenhum à matéria do mesmo [pensamento - cmg]. ... o que chamamos agora de Lógica [formal - cmg] ... [é] a ciência das leis necessárias do entendimento e da razão em geral, ou ... da mera forma do pensamento em geral", ou "a Lógica (formal) é a "ciência das leis necessárias do entendimento e da razão, ou - o que dá no mesmo - da mera forma (itálicos acrescentados - cmg) do pensamento em geral" (Kant,

Germinal: Marxismo e Educação em Debate, Salvador, v. 12, n. 3, p. 45-76, out. 2020. $\quad$ ISSN: 2175-5604 
p. 30). Isto significa que, "Interpretadas como leyes formales, son verdaderas por su forma, independientemente del contenido; esto quiere decir que son verdaderas respecto de cualquier objeto en cualquier mundo posible" (Comey, p. 53). Este é o exato oposto da espirituosa argumentação contrária de Hegel, exposta a seguir.

${ }^{36} \mathrm{Na}$ passagem indicada por Lênin, Hegel classifica como preconceito a idéia de "que através dela [a lógica - cmg] se aprenda a pensar, (...) como se somente após estudar Anatomia e Fisiologia aprendêssemos a digerir e nos movimentar ..." (Hegel, 1990, p. 14, tradução livre). A anatomia e a fisiologia não são ciências que ensinam o ser humano a caminhar e a digerir, respectivamente. Ao contrário, estas ciências procuram, através da pesquisa, explicar teoricamente o caminhar e o digerir espontâneos do ser humano. Do mesmo modo, o ser humano não necessitou que a lógica viesse ensiná-lo a pensar, ao contrário, a lógica é que resultou do desenvolvimento espontâneo da capacidade de pensar do ser humano ao longo de uma prática multi-milenar. Assim, do mesmo modo que a fisiologia procura identificar as leis da digestão, a lógica procura identificar as leis do pensamento, tal como podem ser extraídas da observação metódica do processo de pensamento.

37 "Foi preciso que a atividade prática do ser humano levasse sua consciência à repetição das diferentes figuras lógicas milhares de milhões de vezes, antes que estas figuras pudessem adquirir o sentido de axiomas" (Lenin, 1986, p. 170).

38 "A reflexão sobre as formas da vida humana, e, portanto, também sua análise científica, segue sobretudo um caminho oposto ao desenvolvimento real. Começa post festum e, por isso, com os resultados definitivos do processo de desenvolvimento." Estas formas "(...) já possuem a fixidez de formas naturais da vida social, antes que os seres humanos procurem dar-se conta não sobre o caráter histórico dessas formas, que eles antes já consideram imutáveis, mas sobre seu conteúdo" (OCI, p. 73).

${ }^{39}$ Engels expressa-se no mesmo sentido: "primeiro deriva-se do objeto o conceito do objeto, em seguida inverte-se tudo e mede-se o objeto pela sua imagem, o conceito" (Engels, 1976, p. 81, tradução livre).

40 A crítica de Lukács é endereçada especialmente à aplicação da dialética à natureza, por Engels, no Anti-Dühring: "Os equívocos suscitados pela maneira engelsiana de expor a dialética derivam essencialmente de que Engels - seguindo o mau exemplo de Hegel - estendeu o método dialético ao conhecimento da natureza [Lukács omite, ou ignora, o fato de que Marx fez o mesmo (Marx e Engels, 1975), como indicado adiante - cmg] ...' " (Lukács, 1981, p. 64). Mas Burkett, após exaustiva pesquisa textual, concluiu que Lukács oscilou, ao longo de toda a sua obra, entre a aceitação e a rejeição da validade da dialética na natureza (Burkett, 2013). Crítica do mesmo tipo, embora com outra base, foi formulada por Sartre (1966, p. 34ss). Mas as críticas decepcionam por não apontarem uma explicação para o movimento, a transformação, na natureza, como alternativa à dialética.

${ }^{41}$ Engels enumera as três leis: "a lei da transformação da quantidade em qualidade e vice-versa; a lei da unidade e luta dos contrários; a lei da negação da negação" (Engels, 1961, p. 41), e sugeriu que, como as leis do pensamento refletem as leis da realidade objetiva, pode-se falar em uma dialética objetiva, a dialética do real, e uma dialética subjetiva, a dialética do pensamento (Ibidem, p. 178), correspondentes, mas em sentido materialista, aos títulos dados por Hegel (lógicas objetiva e subjetiva) às $1^{\mathrm{a}}$ e $2^{\mathrm{a}}$ partes, respectivamente, da Ciência da Lógica (Hegel, 1990).

42 "As verdadeiras leis da dialética já existem em Hegel, se bem que em forma mística. É necessário libertá-las dessa forma ..." (Marx, 1974, p. 547). "Todas as três [leis - cmg] são desenvolvidas por Hegel no seu jeito idealista como meras leis do pensamento: a primeira, na primeira parte da sua Lógica [Ciência da lógica - cmg], na Doutrina do Ser; a segunda ocupa toda a segunda e de longe a mais importante parte da sua Lógica, a Doutrina da Essência; finalmente a terceira figura como a lei fundamental para a construção de todo o sistema" (Engels, 1961, p. 41).

43 Engels enuncia uma lei precisa: "... na natureza, de um modo fixado com exatidão em cada caso individual, as mudanças qualitativas só podem ocorrer através da adição quantitativa ou subtração quantitativa de matéria ou movimento (assim chamada energia)" (Engels, 1961, p. 42), opinião posteriormente partilhada por Einstein (Lapp, p. 126).

${ }^{44}$ Hirsch, por exemplo, afirma, enfatica e imprudentemente, que o argumento dialético 'está simplesmente errado: um objeto em movimento está em diferentes lugares em diferentes momentos, não em diferentes lugares no mesmo momento" (Hirsch, 2004).

45 "Inerente a toda essa estrutura [das leis newtonianas - cmg], existe a suposição de que os objetos estão, em dado instante, situados em algum lugar e (...) deslocam-se tranquilamente de um local para outro. Isso parece tão evidente e verdadeiro que quase não vale a pena comentar a respeito. Porém, (...) essa suposição é um preconceito. Podemos realmente ter certeza de que as coisas estão efetivamente aqui ou ali e que elas não estão, na verdade, em dois lugares diferentes ao mesmo tempo? (...) mas, e um elétron dentro de um átomo? Por ora, esse tipo de sugestão parece ser absurda, principalmente porque não conseguimos visualizá-la com nossa mente, porém veremos que é assim que as coisas realmente são" (Cox e Forshaw, 2016, p. 26; Lapp, p. 126).

${ }^{46} \mathrm{Na}$ filosofia soviética, após longo período de preocupação exclusiva com a dialética, retomou-se, a partir de 1946, o ensino e a pesquisa da lógica formal, do ponto de vista materialista dialético (Comey, p. 60-61), desenvolvendo-se duas correntes: a da lógica matemática e a da lógica formal propriamente dita, mas com o surgimento, também, de interpretações formalistas divergentes do materialismo dialético (Chupajin, p. 123-42).

47 Adotamos a expressão 'método teórico' inspirados por uma referência de Marx (1902-3, p. 774).

48 Engels expressa a mesma idéia quando afirma que "... o pensamento consiste tanto em decompor analiticamente os objetos representados na consciência em seus elementos, como em unir os elementos conexos numa unidade. Sem análise, não há síntese" (Engels, 1978a, p. 39/1976, p. 38).

${ }^{49} \mathrm{Na}$ economia política o processo social de elaboração dos abstratos ou conceitos que representam os elementos essenciais do capitalismo e suas interconexões (fase $C_{r} A_{b}$ ) estendeu-se de aproximadamente meados do século 16 até o final do século 18 , quando obteve a sua primeira síntese na obra de Adam Smith, A riqueza das nações, em 1776, ingressando portanto na fase $A_{b} C_{p}$.

$50 \mathrm{O}$ termo concreto refere-se sempre, tanto em Hegel quanto em Marx, a uma totalidade de elementos interconectados, isto é, unidade de múltiplas determinações, definição de Hegel, adotada por Marx. Mas para Hegel o verdadeiro concreto é o concreto do pensamento, que apenas se realiza no real, enquanto para Marx o verdadeiro concreto é o empírico, ou concreto real, do qual o concreto do pensamento, ou concreto pensado, é a representação abstrata.

51 "Se é fácil gerar a representação abstrata ' $a$ fruta' a partir de frutas reais, muito mais difícil é gerar frutas reais a partir da representação abstrata ' $a$ fruta'"' (Engels e Marx, 1973, p. 60). 
52 "... o verdadeiro objeto [da filosofia - cmg] é o Conhecimento em si, e não [o] dos objetos desse Conhecimento que são os fatos ..." (Prado Jr, 1981, p. 22); "A filosofia começa (...) quando surge o pensamento que se pensa a si mesmo ..." (Hegel, 1988, p. 143).

$53 \mathrm{O}$ materialismo dialético pode ser assim considerado porque, como já exposto, o seu primeiro componente, o materialismo, define a realidade objetiva como um todo, sintetizando-a no conceito de matéria, enquanto a dialética materialista expõe as leis que expressam o seu processo de existência. Por outro lado, dizer que o materialismo dialético é uma teoria do existente significa que, como todo conhecimento, o materialismo dialético é uma representação da realidade no e pelo pensamento. Como teoria, é um concreto do pensamento, portanto síntese do diverso, ou seja, um produto da mente que processou o conhecimento emanado da prática - uma prática milenar - sobre o concreto real $(C r)$. Portanto, do ponto de vista lógico, o materialismo dialético, é uma teoria como qualquer outra, diferindo apenas por referir-se ao existente como um todo no maior nível de abstração.

${ }^{54} \mathrm{O}$ que ilustra a afirmação de Engels, de que o método não é uma invenção arbitrária da mente, mas compõe-se das leis extraídas do estudo da realidade objetiva.

55 Por exemplo, o princípio dialético de que a matéria está em movimento permanente converte-se na orientação metodológica de que a pesquisa deve procurar identificar o processo de transformação do objeto de pesquisa - a sociedade $-\mathrm{e}$ as leis que o determinam.

${ }^{56}$ Considerando que a sociedade é constituída pelo conjunto das relações sociais, compostas pelas relações econômicas - as relações de produção, constituintes da base econômica - e as relações ideológicas, residentes na superestrutura, Marx e Engels elaboraram apenas a teoria da base econômica, isto é, das relações de produção, tema d'O capital.

${ }^{57} \mathrm{Na}$ prática o materialismo histórico pode ser - e efetivamente é - utilizado como referência fundamental dos estudos marxistas da sociedade, dispensando o apelo diretamente ao materialismo filosófico e à dialética materialista, talvez uma das causas fundamentais da fragilização teórica, e consequentemente política, do marxismo na atualidade.

58 Pode-se mencionar, como exemplo, a lei da determinação das relação de produção pelas forças produtivas, integrante da teoria do materialismo histórico, que é, portanto, uma lei válida para todas as formas particulares de sociedade, e se converte em lei do método, ou seja, implica que o pesquisador esteja atento para as formas particulares de manifestação da mesma.

59 A primeira exposição da concepção do materialismo histórico foi elaborada por Marx e Engels n'A ideologia alemã, em nível mais abstrato, em oposição à filosofia de Feuerbach, mas o que se pode considerar a primeira versão publicada - em russo, em 1912, e no original em francês em 1913 - é a contida na Carta de Marx a Annenkov, de 1846 (1974c, p. 20), em nível mais concreto da interpretação do capitalismo, mais próxima ao tema do presente artigo. Esta carta é também a primeira versão das suas objeções a Proudhon, publicadas logo depois (Marx, 1978).

${ }^{60}$ Iliénkov, por exemplo, escrevendo na década de 1960, justifica a impossibilidade de elaboração de uma teoria geral do socialismo precisamente com base no fato de haver, à época, somente uma experiência suficientemente desenvolvida, a da URSS, não havendo, portanto, diversas experiências cujos elementos comuns pudessem ser generalizados, ou abstraídos sendo impossível, portanto, naquela época, elaborar uma teoria do socialismo (Iliénkov, p. 47-8). Ver também Engels (NF 84).

${ }^{61}$ Marx e Engels elaboraram, com base no estudo da bibliografia disponível na sua época, a despeito das deficiências desta, os elementos essenciais das teorias gerais dos modos de produção e da transição e, ao elaborar a teoria geral do capitalismo, Marx forneceu elementos fundamentais das teorias geras, respectivamente, do modo de produção feudal e da transição do feudalismo ao capitalismo, contidos n'O capital.

${ }^{62}$ Já se sugeriu, com bom fundamento, que os Grundrisse fornecem uma mirada do 'laboratório de pesquisa' de Marx. Com efeito, o capítulo do dinheiro, desta obra, comparada com a exposição da gênese do dinheiro (DKI, cap. 1), fornece uma ilustração viva da diferença entre os métodos da pesquisa e da exposição, respectivamente. A Contribuição... pode ser considerada um relatório de pesquisa mais avançado sobre o mesmo tema.

63 "Marx fundou uma ciência nova: a ciência da história das formações sociais" - o materialismo histórico - "o maior acontecimento teórico da história contemporânea" (Althusser, 1979, p. 112).

64 "... as formas econômicas nas quais os homens produzem, consomem, trocam, [são - cmg] transitórias e históricas" (Marx, 1974c, p. 22, 25; 1978, p. 28), por exemplo: "... cada modo de produção histórico tem suas leis populacionais particulares, historicamente válidas. Uma lei populacional abstrata só existe para planta e animal (...) (OC1/2, p. 262).

${ }^{65}$ Diversas passagens repetem este princípio fundamental. Por exemplo: "(...) leis naturais da produção capitalista ... Aqui se trata dessas leis mesmo, dessas tendências que atuam e se impõem com necessidade férrea"; ou ainda, "o meu ponto de vista, concebe o desenvolvimento da formação econômica da sociedade como um processo histórico-natural" (DKI, p. 2-3/OCI/1, p. 12-13); "... dentro da produção capitalista, (...) a conexão da produção global se impõe como lei cega aos agentes de produção ..." (OCIII/1, p. 193); e ainda: "...o tempo de trabalho socialmente necessário à sua produção [das mercadorias - cmg] se impõe com violência como lei natural reguladora, do mesmo modo que a lei da gravidade ..." (DKI, p. 54; OCI/1, p. 73, itálicos acrescentados); "... a variação do trabalho agora se impõe apenas como lei natural irresistível e com o cego efeito destrutivo de uma lei natural (DKI, p. 441/ OC1/2, p. 89). "... as conexões do mercado mundial ... aparecem como leis naturais onipotentes, que os dominam contra sua vontade, impondo-se a eles como uma cega necessidade natural" (OCIII/2, p. 280); "... como lei intrínseca, como lei natural cega diante de agentes individuais, é que aqui atua a lei do valor..." (Ibidem, p. 313). A força destas leis observa-se, segundo Marx, inclusive nos níveis mais elementares da organização social, por exemplo: "A lei, que regula a divisão do trabalho comunal, opera aqui com a autoridade inquebrantável de uma lei natural (...)" (DKI. p. 319/OCI/1, p. 281); "Castas e corporações surgem da mesma lei natural que regula a diferenciação de plantas e animais em espécies e subespécies ..." (DKI, p. 301/OCI/1, p. 269). Outras passagens em (OCI/1, p. 120, 148, 206, 224).

66 "As relações de produção de cada sociedade constituem um todo" (Marx, 1977a, p. 130/1978,p. 122). Como as categorias ou conceitos econômicos (por exemplo, dinheiro, capital, juros, etc) são abstrações mentais das relações de produção vigentes na realidade, segue-se que a teoria do modo de produção consiste na exposição do todo mental ou teórico, internamente articulado, constituído pelos conceitos ou abstrações que representam aquelas relações reais, conjunto que, no capitalismo, é o objeto de $O$ capital. 
67 "A sociedade não consiste de indivíduos, mas expressa a soma de vínculos, relações em que se encontram esses indivíduos uns com os outros" (Marx, 2011, p. 205).

68 "As relações sociais estão intimamente articuladas às forças produtivas. Com a obtenção de novas forças produtivas os seres humanos alteram o seu modo de produção, e, com a alteração do modo de produção, do modo de obter seus meios de subsistência, alteram todas as suas relações sociais (Marx e Engels, 1974a, p. 68; 1975, p. 39; Marx, 1978, p. 135).

${ }^{69}$ Uma vertente de tais objeções baseia-se na falsa oposição entre as forças produtivas e as lutas de classes como supostas alternativas de 'motor da história'. Coloca-se, equivocadamente, em ligação direta a base material (as forças produtivas) e o fenômeno social (as lutas de classes) pertencente à esfera política da superestrutura. No entanto, a determinação da luta de classes pelo desenvolvimento das forças produtivas é mediada pelas relações de produção, pois a natureza destas - determinada pelas forças produtivas - é que determina as contradições de classes que, na esfera política, expressam-se na luta de classes e, no momento decisivo, na revolução política.

70 "Não é o que se faz, mas como, com que meios de trabalho se faz, que distingue as épocas econômicas", com destaque para os "meios mecânicos de trabalho [que - cmg] oferecem marcas características muito mais decisivas de uma época social de produção ..." (OCI, p. 151).

71 O estudo da transição integra o estudo das leis de movimento do modo de produção vigente, pois estas leis são responsáveis pelo início da transição, isto é, do declínio do modo de produção vigente. No entanto, como as transições apresentam uma lógica comum, pode-se fazer um corte analítico a fim de tomar como objeto estritamente a transição, que incluiria as fases final do modo de produção vigente e inicial do seguinte.

72 "... todas as épocas da produção têm certas características em comum, determinações em comum. A produção em geral é uma abstração, mas uma abstração razoável, na medida em que efetivamente destaca e fixa o elemento comum (...)" (Marx, 2011a, p. 41). "À medida que o processo social [de produção - cmg] é apenas um mero processo entre homem e Natureza, seus elementos simples continuam sendo comuns a todas as formas sociais de desenvolvimento do mesmo" (OCIII/2, p. 315).

73 Em uma pesquisa sumária nas principais obras econômicas de Marx, nos originais alemães, não se encontrou a utilização do termo determinar, mas apenas corresponder. As razões para isto não estão claras, mas é incontestável que, para Marx, as relações de produção mudam por imposição da mudança das forças produtivas (ver NR 76), o que justifica manter-se, neste artigo, para maior clareza, o termo determinar.

74 O objetivo declarado de Marx ao estudar o capitalismo (OCI/1, p. ..) justificaria acrescentar, a esta definição sintética, que o modo de produção se caracteriza também por uma lei econômica de movimento, própria de cada modo de produção.

75 Parodiando o próprio Marx, os autores "o dizem, mas não o sabem" (OCI/1, p. 72).

76 "Com novas capacidades produtivas adquiridas, os homens mudam seu modo de produção, e, com o modo de produção, mudam todas as relações econômicas, que não são mais do que as relações necessárias dessa determinada forma de produção" (1974c, p. 22-3, itálicos acrescentados);

77 "... os seres humanos não são livres árbitros das suas forças produtivas (...). Devido ao simples fato de que toda geração posterior encontra forças produtivas adquiridas pela geração anterior, forma-se uma concatenação na história dos seres humanos, formase uma história da humanidade" (1974c, p. 21-2). É um fato já trivial que o desenvolvimento histórico dos meios de produção segue o que se poderia denominar trajetórias tecnológicas, em que cada etapa apóia-se na anterior e prepara os elementos da seguinte. Este conceito assemelha-se, mas apenas formalmente, ao de path dependence ou lock-in tecnológicos, da literatura atual sobre o papel das inovações.

78 Esta concepção de Marx sobre a estrutura da sociedade - base técnica/base econômica/superestrutura - é um princípio fundamental do materialismo histórico, que Marx também repete insistentemente do começo ao fim da sua obra, como confirmado por diversas referências expostas neste artigo. É o eixo conceitual do texto da carta a Annenkov (1974c, passim), primeira versão publicada do materialismo histórico, e comparece em todo $O$ capital, até o final do livro III (OCIII/2, p. 315). Um exemplo é a citação literal que Marx faz de parte da passagem acima, no O capital (OCI/1, p. 77, NR33).

${ }^{79}$ Relações de produção é uma forma reduzida, mais utilizada pelo próprio Marx, da forma completa relações sociais de produção e distribuição. A omissão da distribuição, justifica-se porque esta é apenas o reverso da produção, sob a primazia desta. O conjunto de ambas forma as relações econômicas (OCIII/2, p. 884, passim).

80 Por exemplo, "A estrutura econômica da sociedade capitalista emergiu da estrutura econômica da sociedade feudal. A decomposição desta liberou os elementos daquela" (OCI/2, p. 262).

81 "Tendo ... chegado a certo grau de maturidade, a forma histórica determinada [do 'processo social de produção' - cmg] é removida e dá lugar a uma mais elevada" (OCIII/2, p. 315, itálicos acrescentados).

82 "... uma mudança ... nas forças produtivas dos seres humanos necessariamente leva a uma mudança nas suas relações de produção" (Marx, 1978, p. 135, e 199; M/E, 1974b, p. 22, 28 e passim).

83 Cada forma de propriedade, como, por exemplo, "... a propriedade feudal, desenvolve-se em uma série de relações sociais absolutamente distintas [uma da outra - cmg]" (M/E, 1974b, p. 25, itálicos acrescentados).

84 "Surge, então, um conflito entre o desenvolvimento material da produção e sua forma social (OCIII/2, p. 315).

85 A economia política é, portanto, uma ciência essencialmente histórica. A matéria sobre a qual versa é uma matéria histórica, isto é, sujeita a mudança contínua. Seguindo o método da abstração, Engels afirma que "somente depois de investigar as leis específicas de cada etapa concreta de produção e de troca, como conclusão, nos será permitido formular, a título de resumo, as poucas leis verdadeiramente gerais, aplicáveis à produção e à troca, quaisquer que sejam os sistemas" (Engels, 1976, p. 127). "As categorias econômicas não são mais que abstrações destas relações [de produção - cmg] reais", e "são leis apenas para um determinado desenvolvimento histórico", ao contrário do que crêem "os economistas burgueses, que vêem nestas categorias econômicas leis eternas" (Marx, 1974c, p. 26 e passim). 